\title{
Conjugates of Ciprofloxacin and Levofloxacin with Cell-Penetrating Peptide Exhibit Antifungal Activity and Mammalian Cytotoxicity
}

\author{
Natalia Ptaszyńska ${ }^{1,+} \oplus^{\oplus}$, Katarzyna Gucwa ${ }^{1,+}$, Katarzyna Olkiewicz ${ }^{1,+}$, Mateusz Heldt ${ }^{2}{ }^{\oplus}$, \\ Marcin Serocki ${ }^{2}{ }^{\circ}$, Anna Stupak ${ }^{3}$, Dorota Martynow ${ }^{2}$, Dawid Dębowski ${ }^{1}$, \\ Agata Gitlin-Domagalska ${ }^{1}{ }^{1}$, Jan Lica ${ }^{1, *}{ }^{-1}$, Anna Łęgowska ${ }^{1}$, Sławomir Milewski ${ }^{2}{ }^{(1)}$ and \\ Krzysztof Rolka ${ }^{1}$ \\ 1 Department of Molecular Biochemistry, Faculty of Chemistry, University of Gdansk, 80-308 Gdańsk, Poland; \\ natalia.ptaszynska@ug.edu.pl (N.P.); katarzynach3@wp.pl (K.G.); \\ katarzyna.olkiewicz@phdstud.ug.edu.pl (K.O.); dawid.debowski@ug.edu.pl (D.D.); \\ agata.domagalska@ug.edu.pl (A.G.-D.); anna.legowska@ug.edu.pl (A.Ł.); krzysztof.rolka@ug.edu.pl (K.R.) \\ 2 Department of Pharmaceutical Technology and Biochemistry, Faculty of Chemistry, Gdansk University of \\ Technology, 80-233 Gdańsk, Poland; mateusz.heldt@pg.edu.pl (M.H.); marcin.serocki@pg.edu.pl (M.S.); \\ dorota.koperkiewicz@gmail.com (D.M.); slamilew@pg.edu.pl (S.M.) \\ 3 Laboratory of Bacterial Genetics, Faculty of Chemistry, Gdansk University of Technology, \\ 80-233 Gdańsk, Poland; anna.stupak1@pg.edu.pl \\ * Correspondence: 24556@gumed.edu.pl \\ + These authors contributed equally to this work.
}

Received: 25 May 2020; Accepted: 30 June 2020; Published: 30 June 2020

check for updates

\begin{abstract}
Seven conjugates composed of well-known fluoroquinolone antibacterial agents, ciprofloxacin (CIP) or levofloxacin (LVX), and a cell-penetrating peptide transportan $10\left(\mathrm{TP} 10-\mathrm{NH}_{2}\right)$ were synthesised. The drugs were covalently bound to the peptide via an amide bond, methylenecarbonyl moiety, or a disulfide bridge. Conjugation of fluoroquinolones to TP10- $\mathrm{NH}_{2}$ resulted in congeners demonstrating antifungal in vitro activity against human pathogenic yeasts of the Candida genus (MICs in the 6.25-100 $\mu \mathrm{M}$ range), whereas the components were poorly active. The antibacterial in vitro activity of most of the conjugates was lower than the activity of CIP or LVX, but the antibacterial effect of CIP-S-S-TP10- $\mathrm{NH}_{2}$ was similar to the mother fluoroquinolone. Additionally, for two representative CIP and LVX conjugates, a rapid bactericidal effect was shown. Compared to fluoroquinolones, TP10- $\mathrm{NH}_{2}$ and the majority of its conjugates generated a relatively low level of reactive oxygen species (ROS) in human embryonic kidney cells (HEK293) and human myeloid leukemia cells (HL-60). The conjugates exhibited cytotoxicity against three cell lines, HEK293, HepG2 (human liver cancer cell line), and LLC-PK1 (old male pig kidney cells), with IC 50 values in the $10-100 \mu \mathrm{M}$ range and hemolytic activity. The mammalian toxicity was due to the intrinsic cytoplasmic membrane disruption activity of $\mathrm{TP} 10-\mathrm{NH}_{2}$ since fluoroquinolones themselves were not cytotoxic. Nevertheless, the selectivity index values of the conjugates, both for the bacteria and human pathogenic yeasts, remained favourable.
\end{abstract}

Keywords: cell-penetrating peptide (CPP); $\operatorname{transportan} 10$ (TP10- $\left.\mathrm{NH}_{2}\right)$; ciprofloxacin bioconjugates; levofloxacin bioconjugates; antimicrobial agents; bacteriostatic and mycostatic agents; redox-resistant and redox-sensitive linkers

\section{Introduction}

Levofloxacin (LVX) and ciprofloxacin (CIP) are broad-spectrum fluoroquinolone synthetic chemotherapeutics, active against both Gram-positive and Gram-negative bacteria. LVX and CIP are 
used worldwide to treat a number of bacterial infections, including sinusitis, pneumonia, urinary tract infections, tuberculosis, and meningitis. The antimicrobial spectrum of fluoroquinolones is limited to bacteria and does not include human pathogenic eukaryotic microorganisms [1]. Their mammalian toxicity is generally low. Both are on the WHO List of Essential Medicines containing the most effective and safe medicines needed in the health system [2]. Like all fluoroquinolones, LVX, and CIP function by inhibiting bacterial gyrase and topoisomerase IV [3]. Resistance to fluoroquinolones, which is common in staphylococci, enterococci, and Pseudomonas spp., occurs in multiple ways, including alterations in DNA gyrase subunit A, topoisomerase IV, as well as overexpression of multidrug-resistance (MDR) efflux pumps [4].

One of the possibilities to alter the biological properties of chemotherapeutic agents is their chemical modification, including conjugation with oligopeptides, especially those known as the cell-penetrating peptides (CPPs). Such conjugates may possess additional advantages, including an increased selectivity of drug delivery, enhanced efficacy, reduced systemic toxicity, as well as improved pharmacokinetics and pharmacodynamics. Several examples of CPP:drug conjugates have been reported, although most of them concern those of CPPs with anticancer agents [5]. Among very few CPP:antimicrobial agent congeners, those worth mentioning are conjugates of arginine oligomers with triclosan exhibiting promising chemotherapeutic effect in the murine model of toxoplasmosis [6] and peptide-vancomycin conjugates demonstrating enhanced effectiveness against vancomycin-resistant Acinetobacter baumannii and Enterococcus faecalis [7]. The only example of similar derivatisation of fluoroquinolones was enrofloxacin and ciprofloxacin conjugates with $\beta$-octaarginine, showing a similar or lower in vitro antibacterial potential than the mother chemotherapeutics [8]. On the other hand, in our previous studies, we demonstrated some beneficial results of the conjugation of CIP and LVX with antimicrobial peptides (AMPs), namely the lactoferricin truncated analogues [9] and lactoferrin HLopt2 fragment [10].

Cell-penetrating peptides (CPPs), serving as nanocarriers, are considered the fundamental part of a new concept of drug delivery systems [11], which has attacted great interest from many research groups. The unique ability of CPPs to penetrate the plasma membrane makes them a useful tool for the delivery of a vast range of different biologically active compounds to eukaryotic and prokaryotic cells, including proteins, nucleic acids, oligonucleotides, liposomes, nanoparticles, peptides, and low molecular weight chemotherapeutic agents (e.g., doxorubicin, methotrexate, cyclosporine A, paclitaxel [12], and antibiotics [13]). Since the discovery in 1988 of the first cell-penetrating peptide, trans-activator protein (TAT) [14,15], more than 1700 CPPs have been described [16]. One of the well-known CPPs is transportan (TP), a chimeric oligopeptide composed of the first 12 amino acid residues of the neuropeptide galanin and the 14-amino-acid-residue-long wasp venom peptide, mastoparan, connected via a lysine residue [17]. A shorter variant of TP, with deletion of the $\mathrm{N}$-terminal hexapeptide, named TP10- $\mathrm{NH}_{2}$, having an amide moiety at the $\mathrm{C}$-terminus, retains the efficient cell penetration property of the parent compound, with significantly less potential side effects [18]. This peptide amide enters all cell types, including the mammalian ones, and inhibits the growth of some microorganisms, such as Candida albicans, Staphylococcus aureus [19], Streptococcus pneumoniae, and Mycobacterium tuberculosis [20]. TP10- $\mathrm{NH}_{2}$ can transport cargo across cell membranes, applying different mechanisms, dependent on the size and character of the vectors delivered [21]. Recently, Rusiecka and co-workers showed that TP10- $\mathrm{NH}_{2}$ improves the cytotoxic activity of cisplatin against cancer cell lines. Unconjugated TP10- $\mathrm{NH}_{2}$ induces a cytostatic effect on HeLa (cervical cancer) and OS143B (osteosarcoma) cancer cell lines. At the same time, TP10- $\mathrm{NH}_{2}$, as well as TP10- $\mathrm{NH}_{2}$ in complex with cisplatin, had no impact on the cell viability of two non-cancer cell lines HEK 293 (embryonic kidney) and HEL 299 (lung fibroblasts) [22]. TP10- $\mathrm{NH}_{2}$ may thus not only facilitate the transport of an active agent across the microbial cell membranes, but, having an intrinsic antimicrobial activity, it may also potentiate an antimicrobial efficacy of any conjugated antibiotic.

Taking into consideration the literature data mentioned above, we decided to design, synthesise, and determine the antimicrobial activity of conjugates composed of TP10- $\mathrm{NH}_{2}$ and levofloxacin 
or ciprofloxacin. The series of synthesised compounds consisted of five CIP- and two LVX-based conjugates. The conjugation did not improve the antibacterial activity of the mother fluoroquinolones on average. Surprisingly though, they gained activity against human pathogenic yeasts.

\section{Results and Discussion}

\subsection{Chemical Synthesis and Stability Studies}

\subsubsection{Synthesis}

Seven conjugates composed of TP10- $\mathrm{NH}_{2}$ and either levofloxacin or ciprofloxacin were synthesised (Figure 1). In three of them (3, 5, and 6), the constituents were linked by a labile disulfide bridge. Conjugate 7, as a fluorescent representative lacking a disulfide bridge, was synthesised solely for cell penetration studies. Data from the HPLC and MS analyses, as well as the total yields of all final compounds, are given in Table S1. In CIP-CH ${ }_{2} \mathrm{CO}-\mathrm{TP} 10-\mathrm{NH}_{2}(\mathbf{1})$, a methylene carbonyl linker was applied to connect the antibacterial agent through its amino functionality to the $\mathrm{N}$-terminus of TP10- $\mathrm{NH}_{2}$. In CIP-TP10- $\mathrm{NH}_{2}$ (2), an amide bond was formed between the carboxyl group of CIP and the peptide $\alpha$-amino group. An intermolecular disulfide bridge, spanning both components in CIP-S-S-TP10- $\mathrm{NH}_{2}$ (3), was formed using the Lomant's reagent, dithio-bis(succinimidyl propionate). In the LVX-based conjugate LVX-TP10- $\mathrm{NH}_{2}(4)$, the LVX carboxyl group was linked with the $\alpha$-amino group of TP10-NH . In LVXC-S-S-CTP10- $\mathrm{NH}_{2}(5)$ and CIPC-S-S-CTP10-NH $\mathrm{N}_{2}$ (6), the disulfide bridge was formed by Cys residues, attached to both LVX or CIP and the $\mathrm{N}$-terminus of TP10-NH $\mathrm{NH}_{2}$. It was performed by the introduction of the S-(3-nitro-2-pyridylsulfanyl) (Npys) group to the thiol function of Cys attached to Boc-CIP or LVX. In order to determine the cellular uptake of $\mathbf{1}$, its fluorescently labelled analogue $\mathrm{CIP}-\mathrm{CH}_{2} \mathrm{CO}-\mathrm{TP} 10(C f)-\mathrm{NH}_{2}(7), \mathrm{TP} 10(C f)-\mathrm{NH}_{2}$, and $\mathrm{CIP}(C f)$ (reference compounds) were also synthesised. In the first two compounds, 5(6)-carboxyfluorescein was attached to the $\varepsilon$-amino group of thte peptide's Lys residue that replaced Ala in position 12, whereas in $\mathrm{CIP}(C f)$, the fluorophore was introduced to the chemotherapeutic amino group.
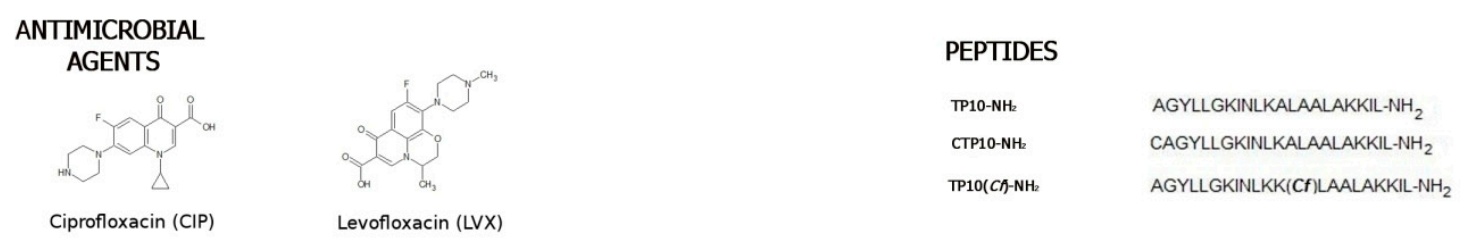

\section{CONJUGATES}
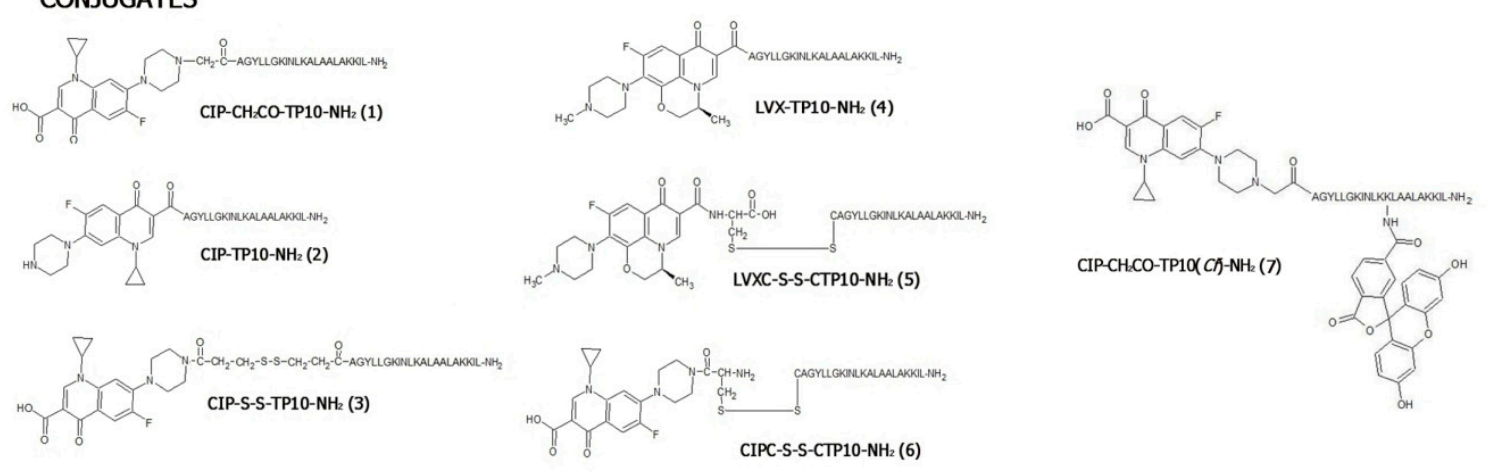

Figure 1. Chemical structures of ciprofloxacin and levofloxacin conjugates with transportan 10 and their constituents. 


\subsubsection{Stability}

In our recent paper [10], we showed that ciprofloxacin conjugated through a disulfide bridge with the antimicrobial peptide named HLopt 2 entered microbial cells. After $2 \mathrm{~h}$ of incubation, in $2 / 3$ of the conjugate molecules that entered microbial cells, the linker was reduced but remained intact when incubated for $2 \mathrm{~h}$ with supernatant obtained from $S$. aureus culture. We obtained similar results for CIP-S-S-TP10-NH $\mathrm{N}_{2}$ (3). Preliminary LC-MS analysis revealed that under the same condition, four peaks were identified. They corresponded to intact conjugate (m/z 2685.56), HS- $\left(\mathrm{CH}_{2}\right)_{2} \mathrm{CO}-\mathrm{TP} 10-\mathrm{NH}_{2}$ $\left(\mathrm{m} / \mathrm{z}\right.$ 2268.41), its dimer (m/z 4534.86), and CIP-CO $\left(\mathrm{CH}_{2}\right)_{2}-\mathrm{SH}\left(\mathrm{m} / \mathrm{z} 420.14 ;[\mathrm{M}+\mathrm{H}]^{+}\right)$(Figure S1). Unlike antimicrobial peptide HLopt2, which was quickly further degraded [10], TP10- $\mathrm{NH}_{2}$ was resistant inside the bacterial cells. The identified dimer of $\mathrm{HS}-\left(\mathrm{CH}_{2}\right)_{2} \mathrm{CO}-\mathrm{TP} 10-\mathrm{NH}_{2}$ is a product of peptide oxidation inside the MS spectrometer.

LC-MS analysis of conjugate 3 proved that the disulfide bridge used as a linker between the peptide and antimicrobial is reduced inside the cell, and both components', CIP and TP10- $\mathrm{NH}_{2}$, derivatives can interact with the targets inside the cell. Both are equipped with thiol groups that can also interact in the cytoplasm with glutathione and other compounds containing $\mathrm{SH}$ groups, modifying conjugate constituents. In addition, TP10- $\mathrm{NH}_{2}$, acting as CPP peptide, helps CIP to pass through the membrane.

CIP-S-S-TP10- $\mathrm{NH}_{2}$ was stable in phosphate-buffered saline (PBS) and growth media used for the determination of antibacterial and antifungal in vitro activity.

\subsection{Antibacterial Activity}

\subsubsection{Bacteriostatic Activity}

The antibacterial activity of TP10- $\mathrm{NH}_{2}$-based conjugates, as well as its constituents, was evaluated by microdilution assay in Mueller Hinton broth, MHB (Table 1). CIP and LVX exhibited a strong antibacterial effect, with the minimal inhibitory concentration (MIC) values in the $0.0125-0.8$ $\left(\mathrm{MIC}_{50}\right) / 1.6 \mu \mathrm{M}\left(\mathrm{MIC}_{90}\right)$ range. TP10- $\mathrm{NH}_{2}$ transportan displayed the highest activity against Escherichia coli and Staphylococcus epidermidis, with an $\mathrm{MIC}_{90}$ value equal to $1.6 \mu \mathrm{M}$, while the Gram-negative bacterium Pseudomonas aeruginosa appeared resistant (MIC $>100 \mu \mathrm{M}$ ). Slightly higher MIC values for TP10- $\mathrm{NH}_{2}$ against Staphylococcus aureus ATCC 25,923 and E. coli ATCC 25,922 (both $16 \mu \mathrm{g} / \mathrm{mL}$, corresponding to $\sim 7 \mu \mathrm{M}$ ) were obtained by Xie and co-workers [23]. The antibacterial activity of most of the novel conjugates of CIP and LVX with TP10- $\mathrm{NH}_{2}$ (1-6) was generally lower than that of the constituent fluoroquinolones. There are, however, some exceptions. Among the conjugates, the highest activity was found for CIP-S-S-TP10- $\mathrm{NH}_{2}$ (3), which displayed slightly better or similar activity against $S$. epidermidis and E. coli compared to CIP. Its activity against two other tested bacteria was somewhat lower though. The activity of the conjugate with CIP directly attached to TP10- $\mathrm{NH}_{2}$ (2) was slightly lower (MIC values in the $0.8-3.125 \mu \mathrm{M}$ range). Further reduction of the antimicrobial activity was observed when CIP was linked to TP10- $\mathrm{NH}_{2}$ by the disulfide bridge between two Cys residues (compound 6). Undoubtedly, the lowest activity was noted for the CIP- $\mathrm{CH}_{2} \mathrm{CO}-\mathrm{TP} 10-\mathrm{NH}_{2}$ (1) conjugate. The LVX-based conjugates 4 and 5 were less active than the CIP-based 1, 2, 3, and $\mathbf{6}$. LVX-TP10- $\mathrm{NH}_{2}(4)$ demonstrated moderate activity against Gram-positive bacteria ( $\left.\mathrm{MIC}_{90}=1.6 \mu \mathrm{M}\right)$, but Gram-negative bacteria were much less susceptible. The conjugate LVXC-S-S-CTP10- $\mathrm{NH}_{2}$ (5), having both components connected via the disulfide bridge formed by cysteine residues, was more active against the Gram-negative bacteria than 4, but its activity against Gram-positive bacteria was lower. 
Table 1. Antibacterial activity of TP10- $\mathrm{NH}_{2}$ conjugates and its constituents in Mueller Hinton broth (MHB).

\begin{tabular}{|c|c|c|c|c|c|c|c|c|}
\hline \multirow{4}{*}{ Compound } & \multicolumn{8}{|c|}{$\mathrm{MIC}[\mu \mathrm{M}]$} \\
\hline & \multicolumn{4}{|c|}{ Gram (+) } & \multicolumn{4}{|c|}{ Gram (-) } \\
\hline & \multicolumn{2}{|c|}{$\begin{array}{c}\text { S. aureus } \\
\text { ATCC } 29213\end{array}$} & \multicolumn{2}{|c|}{$\begin{array}{l}\text { S. epidermidis } \\
\text { ATCC } 12228\end{array}$} & \multicolumn{2}{|c|}{$\begin{array}{c}\text { E. coli } \\
\text { ATCC } 25922\end{array}$} & \multicolumn{2}{|c|}{$\begin{array}{l}\text { P. aeruginosa } \\
\text { ATCC } 27853\end{array}$} \\
\hline & $\mathrm{MIC}_{90}$ & $\mathrm{MIC}_{50}$ & $\mathrm{MIC}_{90}$ & $\mathrm{MIC}_{50}$ & $\mathrm{MIC}_{90}$ & $\mathrm{MIC}_{50}$ & $\mathrm{MIC}_{90}$ & $\mathrm{MIC}_{50}$ \\
\hline CIP & 0.2 & 0.2 & 1.6 & 0.8 & 0.0125 & $<0.0125$ & 0.4 & 0.4 \\
\hline LVX & 0.4 & 0.4 & 1.6 & 0.8 & 0.025 & 0.025 & 0.8 & 0.8 \\
\hline TP10-NH ${ }_{2}$ & 3.125 & 3.125 & 1.6 & 1.6 & 1.6 & 1.6 & $>100$ & $>100$ \\
\hline 1 & 12.5 & 12.5 & 12.5 & 6.25 & 25 & 25 & $>100$ & $>100$ \\
\hline 2 & 0.8 & 0.8 & 1.6 & 1.6 & 1.6 & 1.6 & 3.25 & 3.25 \\
\hline 3 & 0.8 & 0.8 & 0.8 & 0.8 & 0.025 & 0.0125 & 1.6 & 0.8 \\
\hline 4 & 1.6 & 1.6 & 1.6 & 1.6 & 50 & 50 & 100 & 100 \\
\hline 5 & 6.25 & 6.25 & 3.125 & 3.125 & 3.125 & 3.125 & 25 & 12.5 \\
\hline 6 & 3.125 & 3.125 & 6.25 & 6.25 & 6.25 & 6.25 & $>100$ & $>100$ \\
\hline
\end{tabular}

Further investigation was conducted to determine the antibacterial effect of the equimolar mixtures of CIP or LVX with TP10- $\mathrm{NH}_{2}$. The results are listed in Table S2 with the compared values for the mixture components. This data indicates that the fluoroquinolones and the peptide in combination do not act synergistically.

Additionally, for selected compounds, the aspect of the influence of salts present in the medium on antimicrobial activity was evaluated. For that purpose, antibacterial activity in MHB was compared to that in the MHB2 medium, supplemented with $\mathrm{Ca}(\mathrm{II}), 20-25 \mathrm{mg} / \mathrm{L}$, and $\mathrm{Mg}(\mathrm{II}), 10-12.5 \mathrm{mg} / \mathrm{L}$. Data shown in Table S3 indicate that the presence of salts strongly affected the antibacterial activity of TP10- $\mathrm{NH}_{2}$ but had very little, if any, influence on the activity of the conjugates. In the salt-enriched medium, the MIC values determined for TP10- $\mathrm{NH}_{2}$ were up to 40 -fold higher than those found in MHB. The phenomenon of reduction of the growth inhibitory activity of antimicrobial peptides at a high salt concentration was previously evidenced by other researchers [24,25]. It may cause severe limitations for AMPs' usage as therapeutic agents because of the risk of potential inactivation by salts present in the human body. We also observed a slight decrease of antibacterial activity in MHB2 for conjugates 1 and 6 . However, the MICs of conjugates 3 and 4 in MHB and MHB2 were identical or only slightly different.

\subsubsection{Long-Term Resistance Development}

The E. coli ATCC 25,922 and S. aureus ATCC 29,213 cells were serially passaged (10 times) on Mueller Hinton agar (MHA) plates in the presence of CIP $(0.012$ and $0.1875 \mu \mathrm{M}$, respectively) or CIP-S-S-TP10- $\mathrm{NH}_{2}$ (3) (0.012 and $0.375 \mu \mathrm{M}$, respectively). The MIC values were determined under standard conditions against cells collected from colonies grown at the initial plate and plates after the 5 th and the 10th passage. An analogous determination was performed for the control cells, passaged without exposure to antimicrobials. As shown in Figure 2, in the case of E. coli cells, the MIC values for CIP remained unchanged for control cells and increased 8-fold for cells after the 5th and the 10th passage. Similarly, MIC values for the conjugate 3 remained unchanged for the control cells, while for the cells exposed to compound 3, increased only 4-fold after the 5th passage but 32-fold after the 10th one.

The S. aureus resistance to CIP and compound 3 (Figure 2) developed at lower rates than that of $E$. coli since only a 2-fold increase of the MIC values of both agents compared to the control was observed. 

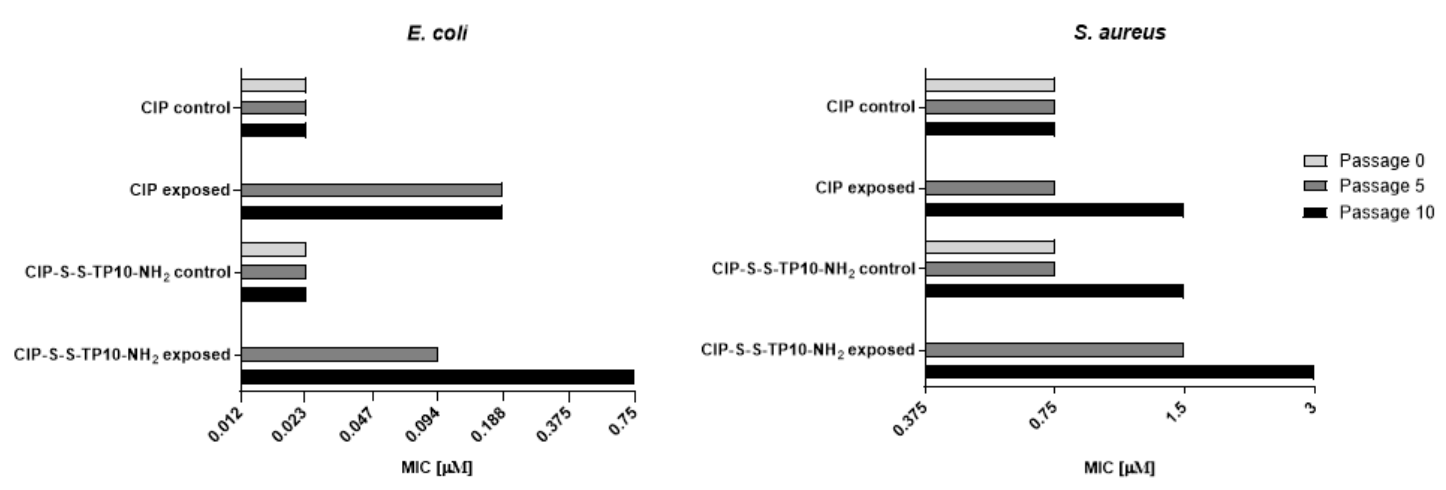

Figure 2. Possibility of resistance development for ciprofloksacin and CIP-S-S-TP10-NH2 (3) by Escherichia coli (left) and Staphylococcus aureus (right) after prolonged exposure to their action. Cells were passaged 10 times on Mueller Hinton agar plates with the addition of given compounds in the maximal concentrations allowing growth. MIC values were marked initially and after the 5th and the 10 th passage and compared to the control. The mean values of three repeats are presented.

\subsection{Bactericidal Effect}

\subsubsection{Minimal Bactericidal Concentration}

The minimal bactericidal concentration (MBC) was determined for TP10- $\mathrm{NH}_{2}$ as well as conjugates $\mathbf{3}$ and $\mathbf{5}$ (Table S4). The selected compounds exhibited bactericidal activity against four tested bacteria strains (concentrations ranging from 3.12 to $100 \mu \mathrm{M}$ ). The lowest MBC value was obtained for conjugate 3. The conjugates 3 and $\mathbf{5}$ were superior to TP10- $\mathrm{NH}_{2}$ transportan for E. coli, P. aeruginosa, and S. aureus. However, no significant difference was noted for B. subtilis. The ratio of $\mathrm{MBC}$ to $\mathrm{MIC}_{90}$ for conjugate 5 was 2.0 for all tested bacteria strains.

\subsubsection{Kinetics of Bactericidal Effect}

As described before, fluoroquinolone conjugates with $\mathrm{TP} 10-\mathrm{NH}_{2}$ are active against both Gram-positive and Gram-negative bacteria, with MBCs reaching micromolar levels (Table S4). Furthermore, UV-induced fluorescence of fluoroquinolones allowed observation of conjugate localisation. Differential live-dead bacteria staining was performed for conjugate 5 at MBC (Figure 3). After $10 \mathrm{~min}$ of incubation with conjugate 5, the green fluorescence (vital) was decreased with a simultaneous increase in red fluorescence (dead), a result of disruption of the membrane integrity marked by Syto 9 displacement by propidium iodide. Dead cells exhibited concurrent UV-inducible blue fluorescence emission (conjugate accumulation), illustrating the bactericidal properties of the conjugate 5. No significant discrepancies in the results were noted between Gram-positive (B. subtilis) and Gram-negative (E. coli) representatives.

Additionally, real-time transmitted light and fluorescence microscopy were performed for conjugate 5 at MBC. Conjugate 5 was able to penetrate four tested bacteria strains and decrease their mobility (Videos S1-S4). Conjugate 5 accumulated in the cells within the first minute after addition. After $15 \mathrm{~min}$, the majority of the cells showed a considerable decrease in mobility and fluorescence corresponding to the conjugate. In this experiment, the compound penetrated the cells faster in the case of the Gram-negative than Gram-positive bacteria, thereby affecting their mobility. 
A

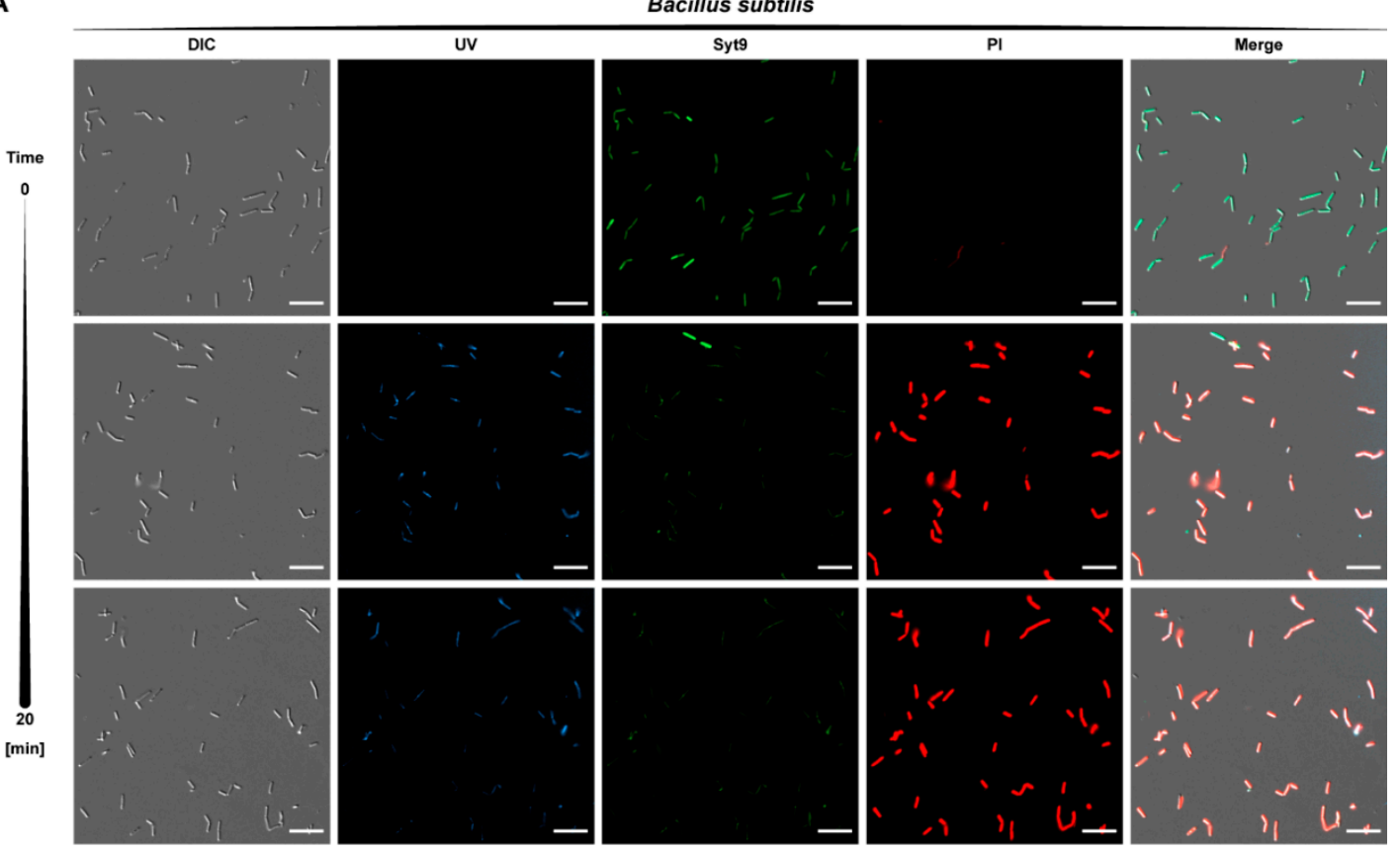

B

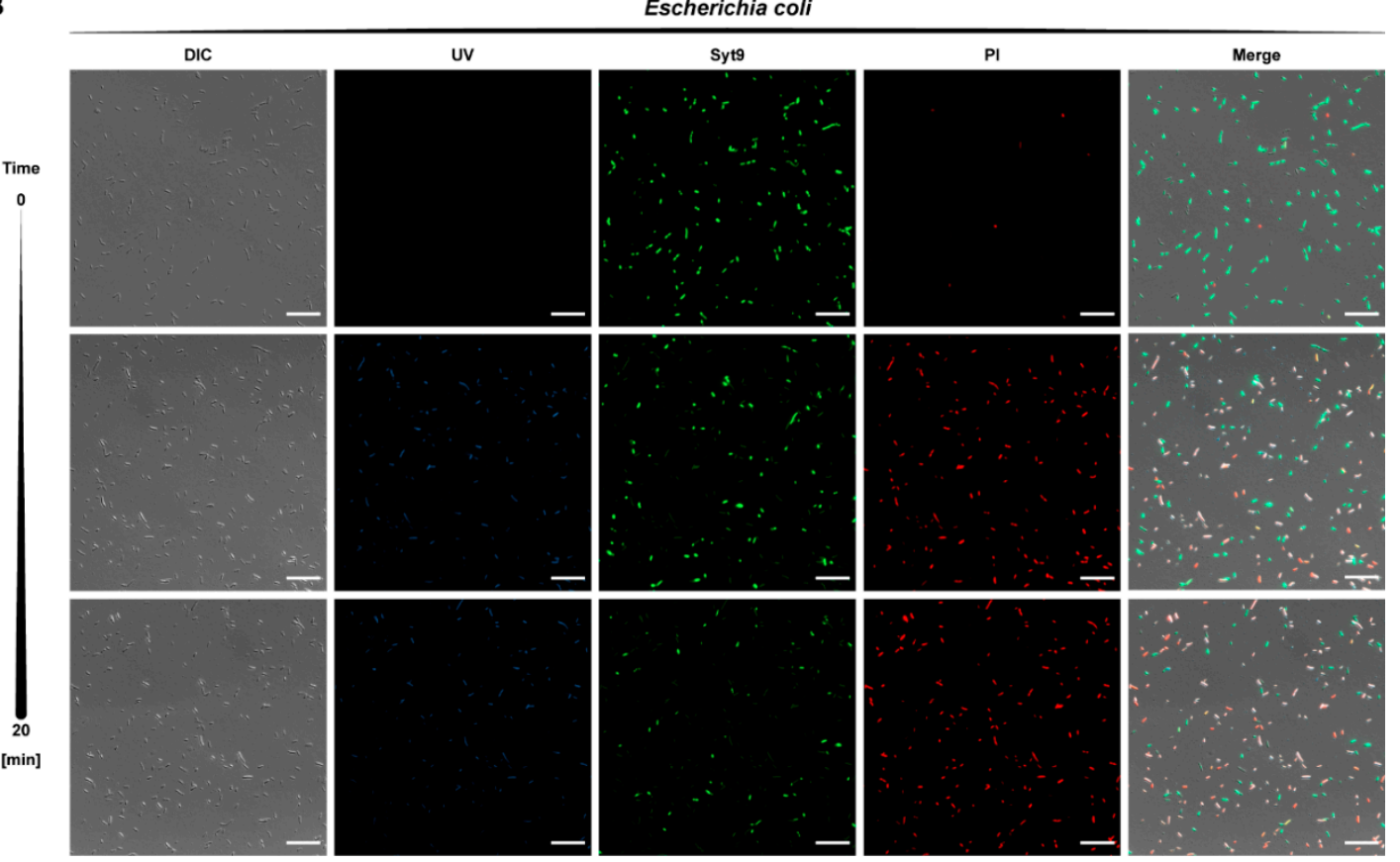

Figure 3. Death kinetics of (A) B. subtilis and (B) E. coli treated with conjugate 5 at Minimal Bactericidal Concentration followed over $20 \mathrm{~min}$. Within the first $10 \mathrm{~min}$ of incubation, the compound penetrates the cells (blue) and disrupts the membrane, which allows the uptake of propidium iodide (PI, red), displacing DNA-bound Syto 9 (green). No morphological alterations were observed. Scale bars correspond to $20 \mu \mathrm{m}$.

\subsection{Antifungal Activity}

The antifungal in vitro activity of CIP, LVX, TP10-NH2, and conjugates 1-6 was evaluated against six strains of the Candida genus, including three reference strains, the C. albicans mutant lacking genes coding for peptide permeases, and two clinical C. albicans strains Gu4 and Gu5. Gu4 is a Fluconazole (FLU)-sensitive isolate obtained from an early infection episode, while Gu5 is the corresponding FLU-resistant isolate obtained from a later episode in the same patient treated with FLU. The Gu5 
isolate is resistant to FLU, due to the FLU-induced overexpression of genes encoding the drug efflux pump encoded by the CDR1/CDR2 genes, and Gu4 exhibits a basal expression of these genes [26].

The MIC values obtained are shown in Table 2. No growth inhibition of all strains by the fluoroquinolones CIP and LVX at concentrations up to $200 \mu \mathrm{M}$ was observed, while TP10- $\mathrm{NH}_{2}$ exhibited poor activity exclusively against $C$. albicans $(\mathrm{MIC}=100 \mu \mathrm{M}$ ). The activity of the conjugates 1-6 was generally higher than that of their components The highest activity was observed for CIP conjugates 2, 3, and 5 (MICs in the 6.25-100 $\mu \mathrm{M}$ range). The C. glabrata strain was resistant to the action of all the tested compounds. The MIC values of TP10- $\mathrm{NH}_{2}$ and conjugates against the C. albicans peptide permeases-deficient mutant were the same or slightly lower than those against the wild-type strains. This finding suggests that these compounds are not transported through the cell membrane by peptide permeases. The MIC values of all conjugates against $C$. albicans and $C$. krusei were in most cases lower than those of the established antifungal drug, Fluconazole. The FLU-resistant clinical Gu5 strain was sensitive to conjugates 1-6 at the same level like its FLU-sensitive counterpart Gu4.

Table 2. The antifungal activity of CIP, LVX, TP10- $\mathrm{NH}_{2}$, and conjugates 1-6.

\begin{tabular}{|c|c|c|c|c|c|c|c|c|}
\hline \multirow{3}{*}{ Compound } & \multicolumn{8}{|c|}{$\mathrm{MIC}[\mu \mathrm{M}]$} \\
\hline & \multicolumn{2}{|c|}{$\begin{array}{l}\text { C. albicans } \\
\text { SC } 5314\end{array}$} & \multicolumn{2}{|c|}{$\begin{array}{c}\text { C. albicans } \\
\Delta \text { opt } 1 \Delta \text { opt } 5 \Delta \operatorname{ptr} 2 \Delta \operatorname{ptr} 22\end{array}$} & \multirow{2}{*}{$\begin{array}{c}\begin{array}{c}\text { C. albicans } \\
\text { Gu4 }\end{array} \\
\mathrm{MIC}_{50}\end{array}$} & \multirow{2}{*}{$\begin{array}{c}\begin{array}{c}\text { C. albicans } \\
\text { Gu5 }\end{array} \\
\mathrm{MIC}_{50}\end{array}$} & \multirow{2}{*}{$\begin{array}{c}\begin{array}{c}\text { C. glabrata } \\
\text { DSM } 11226\end{array} \\
\text { MIC }_{50}\end{array}$} & \multirow{2}{*}{$\begin{array}{c}\begin{array}{c}\text { C. krusei } \\
\text { DSM } 6128\end{array} \\
\text { MIC }_{50}\end{array}$} \\
\hline & $\mathrm{MIC}_{90}$ & $\mathrm{MIC}_{50}$ & $\mathrm{MIC}_{90}$ & $\mathrm{MIC}_{50}$ & & & & \\
\hline CIP & $>200$ & $>200$ & $>200$ & $>200$ & $>200$ & $>200$ & $>200$ & $>200$ \\
\hline LVX & $>200$ & $>200$ & $>200$ & $>200$ & $>200$ & $>200$ & $>200$ & $>200$ \\
\hline TP10-NH 2 & 100 & 100 & 100 & 100 & 100 & 100 & $>200$ & $>200$ \\
\hline 1 & 100 & 50 & 200 & 100 & 50 & 50 & $>200$ & 50 \\
\hline 2 & 12.5 & 12.5 & 12.5 & 6.25 & 25 & 25 & $>200$ & 50 \\
\hline 3 & 25 & 6.25 & 25 & 12.5 & 6.25 & 12.5 & $>200$ & 25 \\
\hline 4 & 100 & 50 & 100 & 100 & 25 & 25 & $>200$ & 100 \\
\hline 5 & 25 & 12.5 & 25 & 12.5 & 12.5 & 12.5 & $>200$ & 50 \\
\hline 6 & 50 & 50 & 50 & 50 & 25 & 25 & $>200$ & $>200$ \\
\hline FLU & 100 & 50 & 100 & 50 & 50 & $>200(1600)$ & 100 & 50 \\
\hline
\end{tabular}

\subsection{Molecular Mechanism of Antifungal Activity}

\subsubsection{Cellular Uptake}

Figure 4 clearly demonstrates the qualitative difference in the uptake of the analysed compounds to $C$. albicans and $C$. glabrata. Both TP10 $(C f)-\mathrm{NH}_{2}$ and $C I P-\mathrm{CH}_{2} \mathrm{CO}-\mathrm{TP} 10(C f)-\mathrm{NH}_{2}(7)$ were transported to and accumulated in Candida albicans cells, while $\operatorname{CIP}(C f)$ did not enter these cells. On the other hand, none of the fluorescent probes were taken up by Candida glabrata (Figure 4). These results provide a rational explanation for the lack of antifungal activity of CIP and LVX, as well as for the apparent resistance of Candida glabrata to fluoroquinolones, TP10- $\mathrm{NH}_{2}$, and the conjugates. The uptake of $\mathrm{CIP}-\mathrm{CH}_{2} \mathrm{CO}-\mathrm{TP} 10(C f)-\mathrm{NH}_{2}$ (7) was time dependent, as evidenced in Figure 5. The confocal images shown in Figure 6 confirm that CIP- $\mathrm{CH}_{2} \mathrm{CO}-\mathrm{TP} 10(C f)-\mathrm{NH}_{2}$ and TP10 $(C f)-\mathrm{NH}_{2}$ taken up by $C$. albicans cells are uniformly distributed in the cytoplasm. 


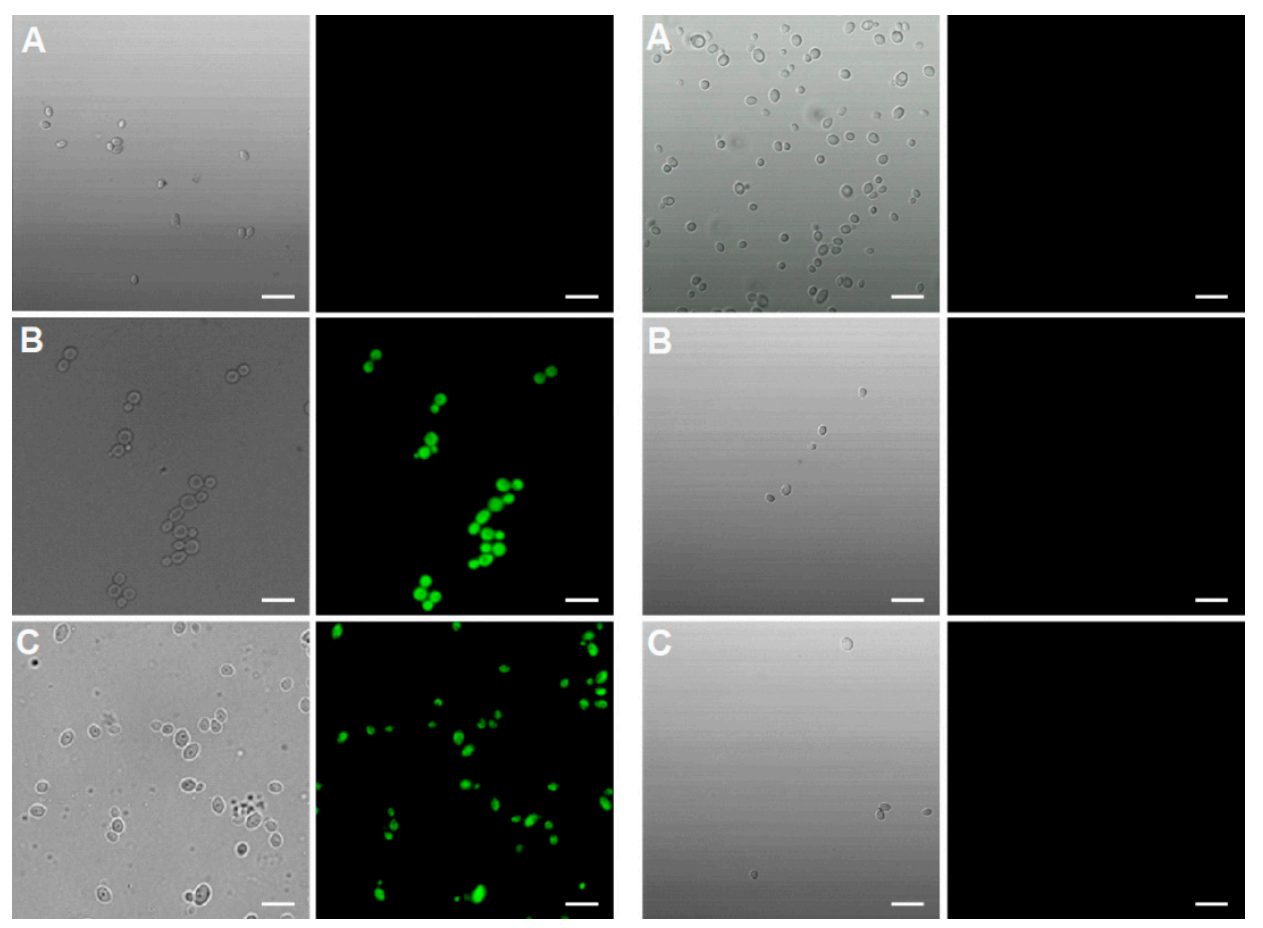

Figure 4. Uptake and accumulation of $(\mathbf{A}) \mathrm{CIP}(\boldsymbol{C} f) ;(\mathbf{B}) \mathrm{TP} 10(\boldsymbol{C} f)-\mathrm{NH}_{2}$; and $(\mathbf{C}) \mathrm{CIP}-\mathrm{CH}_{2} \mathrm{CO}-\mathrm{TP} 10(\boldsymbol{C} f)-\mathrm{NH}_{2}$ (7) in Candida albicans cells-left microphotography column. Right microphotography column-uptake

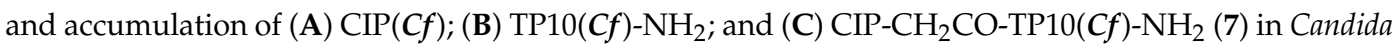
glabrata cells. The fluorescent signal of the compounds is shown in green. Cells were suspended in phosphate-buffered saline and incubated in the presence of fluorescent probes $(40 \mu \mathrm{M})$ for $30 \mathrm{~min}$. Differential interference contrast and fluorescence microscopy. Scale bars correspond to $10 \mu \mathrm{m}$.

\subsubsection{Inhibition of Yeast DNA Topoisomerase II}

Ciprofloxacin, levofloxacin, and other analogue quinolones are well-known inhibitors of bacterial gyrase. Studies showed that fluoroquinolones inhibit this enzyme through DNA binding rather than direct enzyme inhibition $[27,28]$. Fluoroquinolones are also able to inhibit eukaryotic DNA topoisomerases I and II. However, complete inhibition of eukaryotic enzymes requires a much higher concentration of those drugs [29].

In order to check whether tested conjugates inhibit yeast DNA topoisomerase II in the same manner as CIP and LVX alone, the supercoiled plasmid DNA relaxation assay mediated by yeast DNA topoisomerase II was performed. As shown in Figure 7, TP10- $\mathrm{NH}_{2}$ and the studied conjugates were able to inhibit yeast topoisomerase II in a concentration-dependent manner. TP10- $\mathrm{NH}_{2}$ was able to abolish enzyme activity at a concentration of $50 \mu \mathrm{M}$ entirely. CIP-TP10- $\mathrm{NH}_{2}$ (2) and LVX-TP10- $\mathrm{NH}_{2}$ (4) completely inhibited topoisomerase II activity at $10 \mu \mathrm{M}$, whereas LVX-C-S-S-CTP10- $\mathrm{NH}_{2}$ (5) at $50 \mu \mathrm{M}$. Under the experimental conditions, CIP and LVX displayed residual activity at the highest used concentration of $500 \mu \mathrm{M}$.

Both CIP and LVX are fluorescent and thus can be visualised in agarose gel after electrophoresis under UV light without any additional staining. The results of parallel electrophoretic separation of samples from one experiment are shown in Figure 8. Electrophoresis of the relaxation assay samples without previous chloroform/isoamyl extraction step revealed that TP10- $\mathrm{NH}_{2}$ and CIP-TP10- $\mathrm{NH}_{2}$ (2) might interact with DNA in at least two distinct manners. Firstly, we observed relatively weak peptide-DNA interaction (indicated by arrow), which can be destroyed by the chloroform/isoamyl alcohol extraction step. The observed bands are distorted and characterised by a delay in gel mobility compared to the band from the relaxed form of the plasmid DNA. Secondly, we observed relatively strong peptide-DNA interaction (indicated by the dotted rectangle), which cannot be removed by extraction. The bands are sharp and exhibit poor gel mobility. On the colour photographs presented 
on the bottom panel of Figure 7, we observed the co-migration band containing DNA (red fluorescence from $\mathrm{EtBr}$ ) and conjugate (blue fluorescence from CIP-TP10- $\mathrm{NH}_{2}$ (2)). Similar results were obtained for LVX (Figure S2).
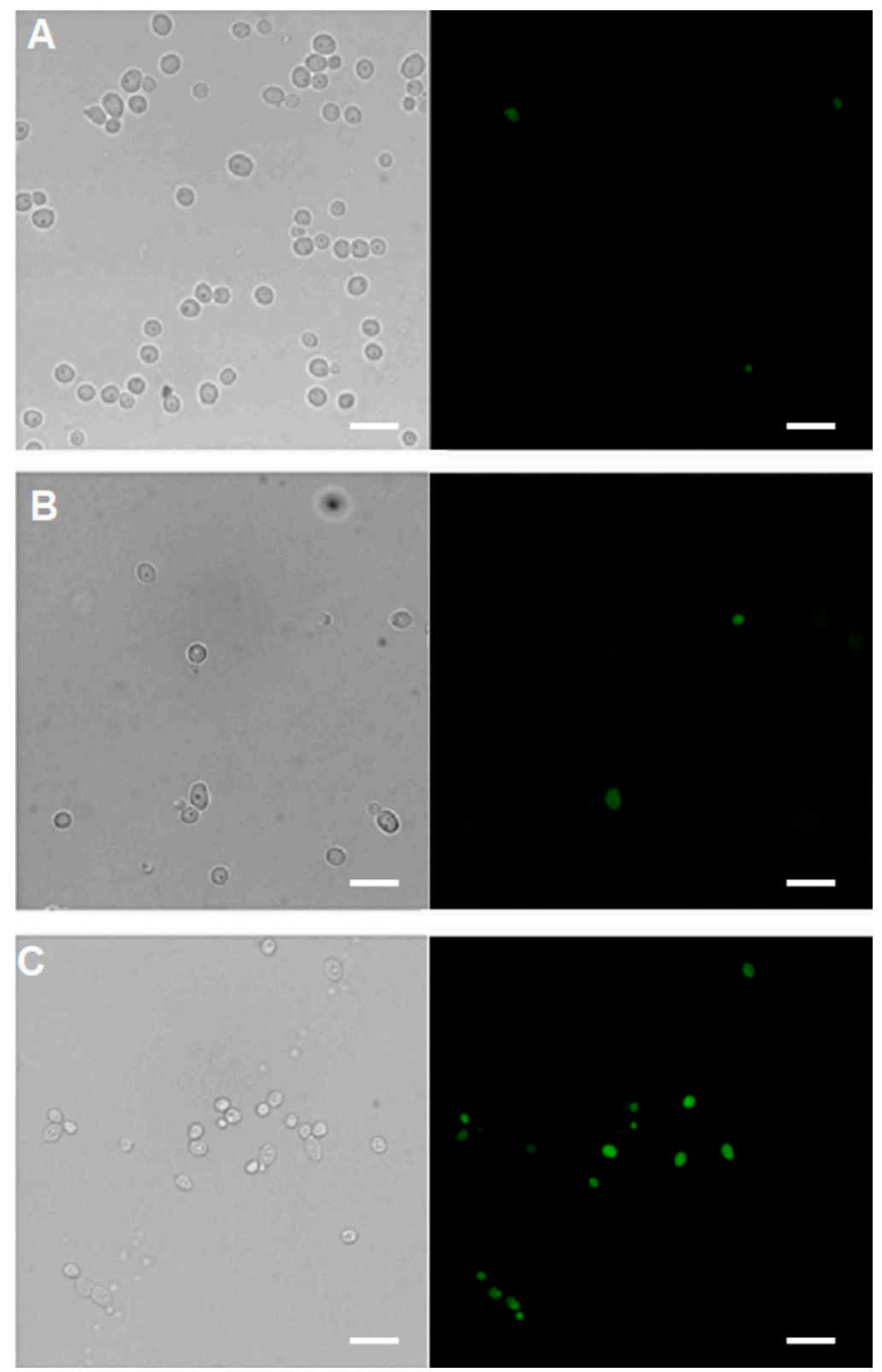

Figure 5. Kinetics of CIP- $\mathrm{CH}_{2} \mathrm{CO}-\mathrm{TP} 10(\mathrm{C} f)-\mathrm{NH}_{2}(7)$ uptake by Candida albicans cells. Pictures were taken after (A) 0, (B) 15, (C) $30 \mathrm{~min}$. Scale bars correspond to $10 \mu \mathrm{m}$. 

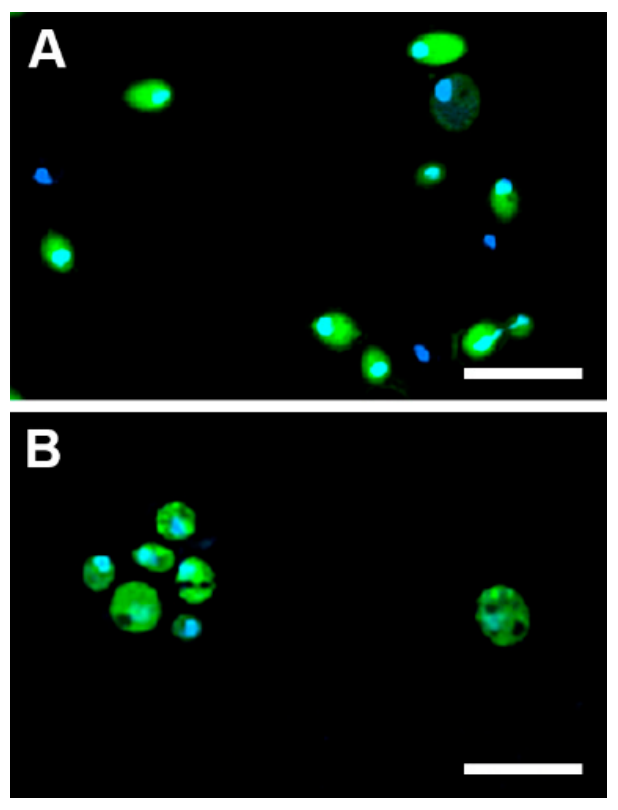

Figure 6. Confocal images of $C$. albicans cells loaded with (A) $\mathrm{CIP}-\mathrm{CH}_{2} \mathrm{CO}-\mathrm{TP} 10(\boldsymbol{C} f)-\mathrm{NH}_{2}(7)$ and (B) $\mathrm{TP} 10(C f)-\mathrm{NH}_{2}$. The fluorescent signal of the compounds is shown in green. Hoechst 33,342 was used to stain nuclei. Scale bars correspond to $10 \mu \mathrm{m}$.

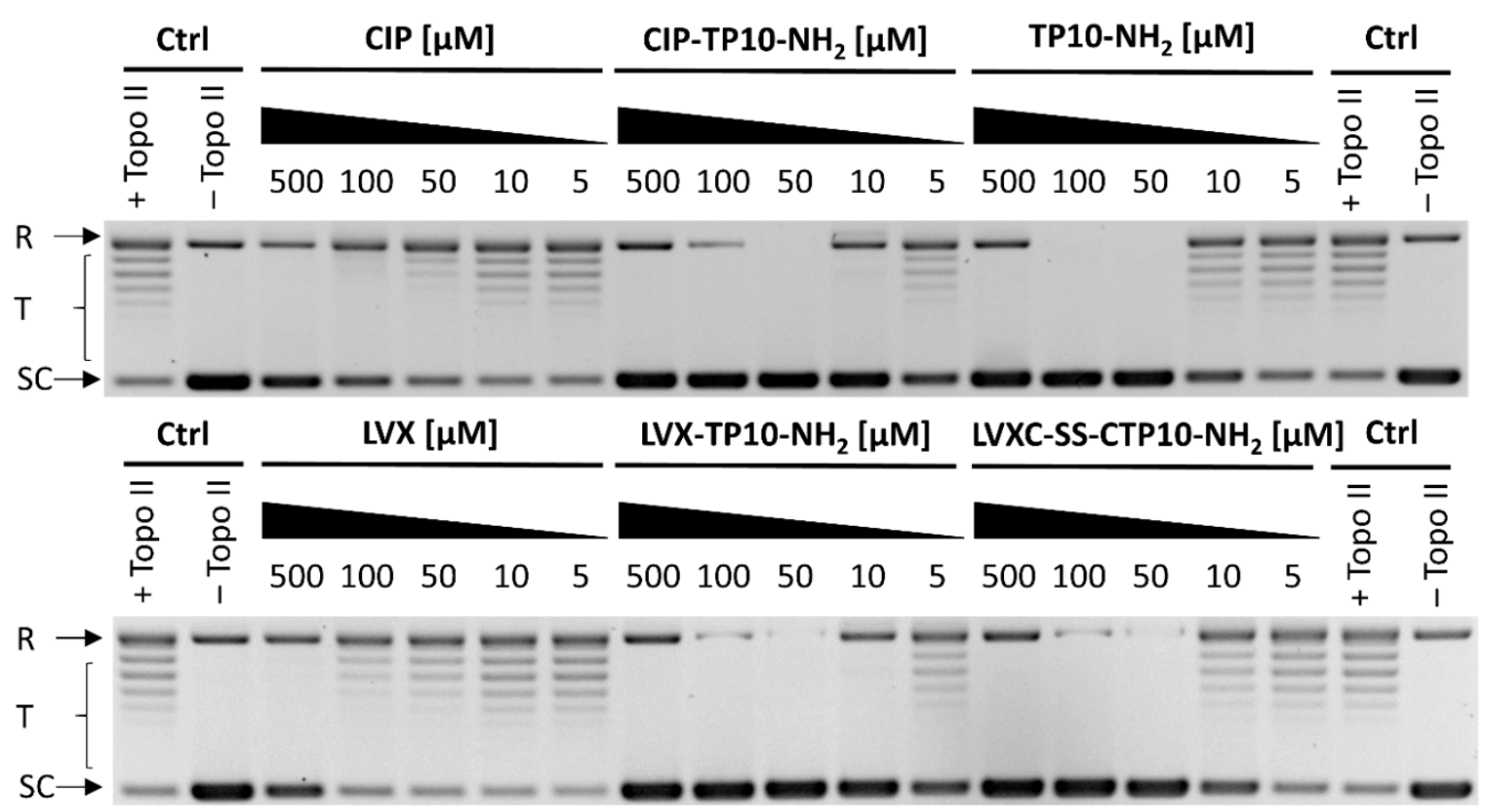

Figure 7. In vitro inhibition of the catalytic activity of pure type II yeast topoisomerase enzyme by fluoroquinolones and their peptide conjugates. R: relaxed DNA, T: DNA topomers, SC: supercoiled DNA. 


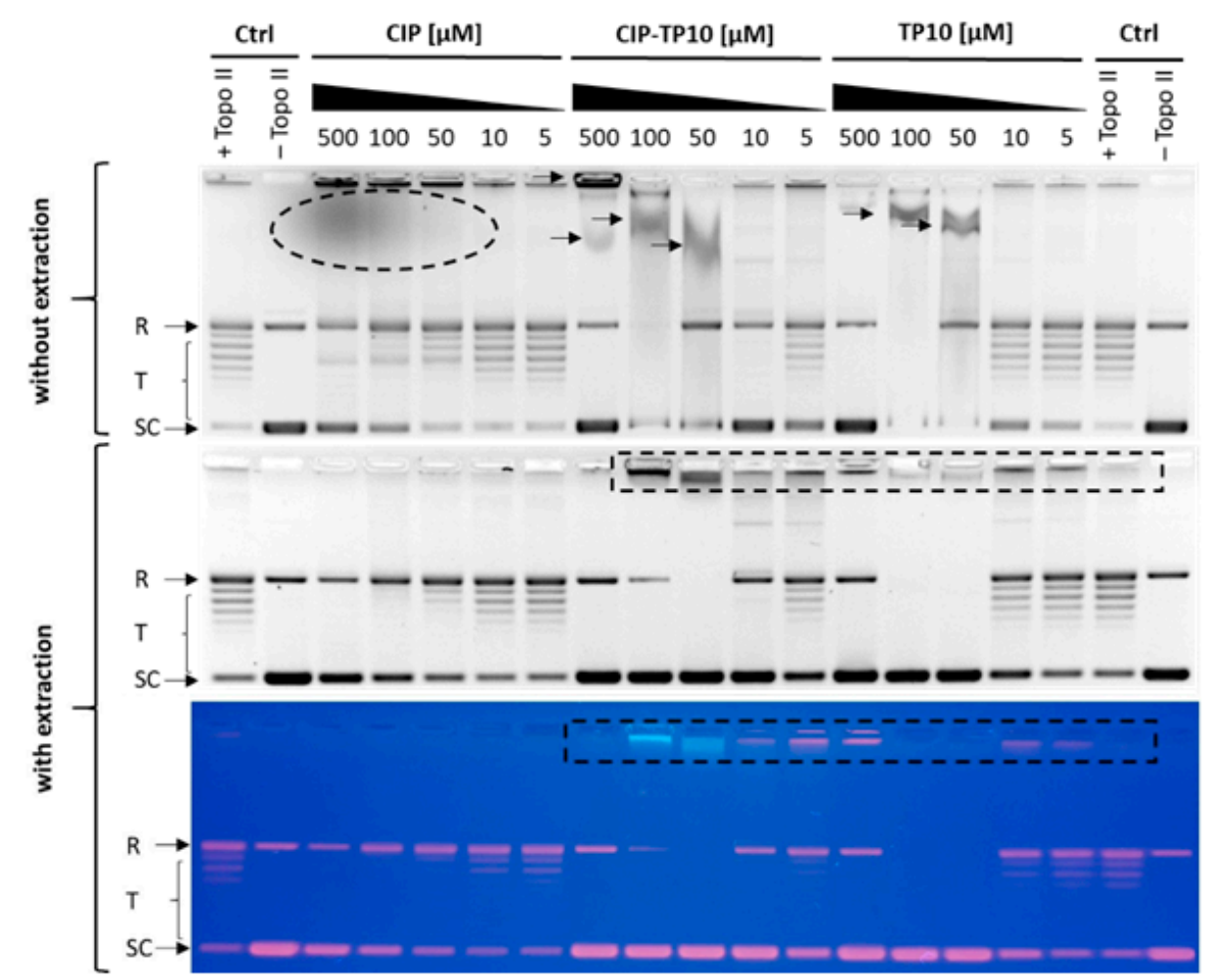

Figure 8. Results of parallel electrophoretic separation of samples from one experiment with the extraction (lower panel) and without extraction step (upper panel). Unbound CIP fluorescence was highlighted with a dotted ellipse. Weak DNA-peptide interactions are marked with arrows. Strong DNA-peptide interactions are highlighted with a dotted rectangle. The bottom colour picture shows comigrating DNA-peptide bands with mixed fluorescence: red from DNA (EtBr) and blue fluorescence from CIP-TP10- $\mathrm{NH}_{2}$ conjugate (highlighted with a dotted rectangle). R: relaxed DNA, T: DNA topomers, SC: supercoiled DNA.

We postulate that TP10- $\mathrm{NH}_{2}$ and its conjugates inhibit DNA topoisomerase II in two different ways. At low concentrations, 5-100 $\mu \mathrm{M}$, the peptide and the conjugate most probably act as direct inhibitors of the enzyme by interacting with a distorted DNA intermediate arising during topoisomerase II-mediated catalysis. This assumption is supported by the observation of vanished bands from mostly unwound (R: relaxed) form of plasmid DNA at the 100 and $50 \mu \mathrm{M}$ peptide concentrations tested and retention of slow-migrating bands after the organic-solvent extraction step. However, we did not observe any slow-migrating bands remaining after extraction at the highest used concentration of TP10- $\mathrm{NH}_{2}$ and its conjugates. We assume that at $500 \mu \mathrm{M}$, the formation of enzyme-DNA intermediate is not possible, probably due to the direct sequestration of negatively charged DNA by positively charged peptide or other factors, i.e., possible changes in $\mathrm{pH}$, direct enzyme inactivation before the DNA binding step.

\subsection{Mammalian Toxicity}

\subsubsection{Cytotoxicity}

The cytotoxicity of CIP, LVX, and conjugates 1-6 was evaluated on three mammalian cell lines: Epithelial, adherent kidney proximal tubule cells isolated from kidney of 3- to 4-week-old male pigs (LLC-PK1), human embryonic kidney cells (HEK 293), and human liver cancer cell line (Hep G2). Fluoroquinolones CIP and LVX were less cytotoxic than TP10- $\mathrm{NH}_{2}$ and the conjugates (Table 3). Among the conjugates, LVXC-S-S-CTP10- $\mathrm{NH}_{2}(5)$ was the least cytotoxic. In the case of Hep G2 cells, the half-maximal inhibitory concentration $\left(\mathrm{IC}_{50}\right)$ value for compound 5 was nine times higher than that for CIP-TP10- $\mathrm{NH}_{2}$ (2), which was found to be the most cytotoxic. In the case of HEK 293 and LLC-PK1 cells, the $\mathrm{IC}_{50}$ values of 5 were nearly four times higher. Two other CIP-based conjugates 
CIP-CH ${ }_{2} \mathrm{CO}-\mathrm{TP} 10-\mathrm{NH}_{2}(\mathbf{1})$ and CIP-S-S-TP10- $\mathrm{NH}_{2}$ (3) were comparably cytotoxic to all three cell lines and similarly to 2 had lower $\mathrm{IC}_{50}$ values than 5 . An approach to attach CIP to TP10- $\mathrm{NH}_{2}$ via the Cys residue appeared to be beneficial in terms of the potential cytotoxicity, as the $\mathrm{IC}_{50}$ values for CIPC-S-S-CTP10- $\mathrm{NH}_{2}(\mathbf{6})$ were more than two times higher than for $\mathbf{2}$ in the case of two cell lines. Additionally, we noted that the cancer cells Hep G2 were less sensitive to the action of the given compounds than the non-cancer cells (HEK 293 and LLC-PK1).

There is little doubt that the observed cytotoxicity of conjugates was due to the effect of the TP10- $\mathrm{NH}_{2}$ component, since the $\mathrm{IC}_{50}$ values of all but the compound 5 conjugates and the peptide were at a similar level, while CIP and LVX were not cytotoxic at all.

Table 3. In vitro cytotoxicity $\left(\mathrm{IC}_{50} \pm \mathrm{SD}(\mu \mathrm{M})\right)$ of selected conjugates and their constituents toward human embryonic kidney cells, G2 human liver cancer cells, and old male pig kidney cells.

\begin{tabular}{cccc}
\hline \multirow{2}{*}{ Compound } & \multicolumn{3}{c}{ IC $_{\mathbf{5 0}} \pm$ SD $[\boldsymbol{\mu M}]$} \\
\cline { 2 - 4 } & HEK 293 & Hep G2 & LLC-PK1 \\
\hline CIP & $>200$ & $>200$ & $>200$ \\
LVX & $>200$ & $>200$ & $>200$ \\
TP10-NH 2 & $25.08 \pm 0.86$ & $32.12 \pm 1.65$ & $22.73 \pm 5.65$ \\
CTP10-NH 2 & $19.47 \pm 2.93$ & $59.97 \pm 5.75$ & $51.60 \pm 8.66$ \\
$\mathbf{1}$ & $10.81 \pm 1.87$ & $21.70 \pm 2.18$ & $17.79 \pm 1.93$ \\
$\mathbf{2}$ & $10.42 \pm 1.39$ & $11.46 \pm 2.03$ & $27.06 \pm 1.82$ \\
$\mathbf{3}$ & $13.11 \pm 1.22$ & $19.03 \pm 2.08$ & $16.83 \pm 2.62$ \\
$\mathbf{4}$ & $22.54 \pm 9.70$ & $72.58 \pm 12.95$ & $52.92 \pm 8.15$ \\
$\mathbf{5}$ & $41.34 \pm 1.10$ & $101.5 \pm 4.90$ & $104.70 \pm 15.62$ \\
$\mathbf{6}$ & $20.84 \pm 10.91$ & $37.71 \pm 2.84$ & $21.33 \pm 1.33$ \\
\hline
\end{tabular}

\subsubsection{Hemolysis}

Additionally, to evaluate the potential mammalian toxicity of the tested compounds, the hemolysis assay was performed. The hemolytic effect of the tested compounds on human red blood cells is shown in Figure 9. TP10- $\mathrm{NH}_{2}$ is known to cause hemolysis, perhaps due to the high content of hydrophobic amino acid residues (62\%) [30,31]; however, in our case, $50 \%$ hemolysis by this peptide was observed at nearly $200 \mu \mathrm{g} / \mathrm{mL}(\sim 92 \mu \mathrm{M})$. Even though antimicrobial drugs CIP and LVX do not cause a hemolytic effect, the conjugates were hemolytic, with $\mathrm{MHC}_{50}$ values (minimum hemolytic concentration that caused $50 \%$ hemolysis of human red blood cells) in the $25-140 \mu \mathrm{g} / \mathrm{mL}$ range. Furthermore, for all congeners, the hemolytic activity was higher than for $\mathrm{TP} 10-\mathrm{NH}_{2}$ alone. A similar effect was recently described by others for TP10- $\mathrm{NH}_{2}$-derived antimalarial conjugates [32]. The LVX congener 5 was the least hemolytic among the conjugates, with $\mathrm{IC}_{50}=140 \mu \mathrm{g} / \mathrm{mL}(\sim 51 \mu \mathrm{M})$, which is in line with its lowest cytotoxicity (Table 3). The most hemolytic was CIP-TP10- $\mathrm{NH}_{2}$ (2), with $\mathrm{MHC}_{50}=25 \mu \mathrm{g} / \mathrm{mL}(\sim 10 \mu \mathrm{M})$. The $\mathrm{MHC}_{50}$ values of the conjugates were much higher than the $\mathrm{MIC}_{50}$ values against bacteria (Table 1) but lower than the $\mathrm{MIC}_{50}$ values against yeasts (Table 2).

\subsubsection{ROS Generation}

The results of reactive oxygen species (ROS) generation are shown in Figure 10. In the positive controls treated with $\mathrm{H}_{2} \mathrm{O}_{2}$, the fraction of ROS-positive cells exceeded $75 \%$. In reference samples treated with CIP, the ROS positive fraction exceeded 50\%. Strikingly, in HL-60, a biologically significant effect was observed almost immediately (after $15 \mathrm{~min}$ of incubation). The same was noted after $1 \mathrm{~h}$ in the HEK 293 cell line. On the other hand, for a 2 and 3, no ROS generation was observed. Similarly, conjugates 4 and 5 generated ROS at the low level (less than 15\% for HL-60 and less than $20 \%$ for HEK 293) (manuscript in preparation). Surprisingly, the two tested cell lines drastically differed in response to conjugate 6. For HL-60, the critical level of ROS was noted after 15 min of incubation. On the contrary, in HEK 293, the conjugate did not induce a significant level of ROS. The fact that the action of most of the synthesised conjugates results in negligible ROS generation is 
advantageous, suggesting low cardio- and hepatotoxicity potential, which stands in strike contrast with bare antibacterial fluoroquinolones [33-35].

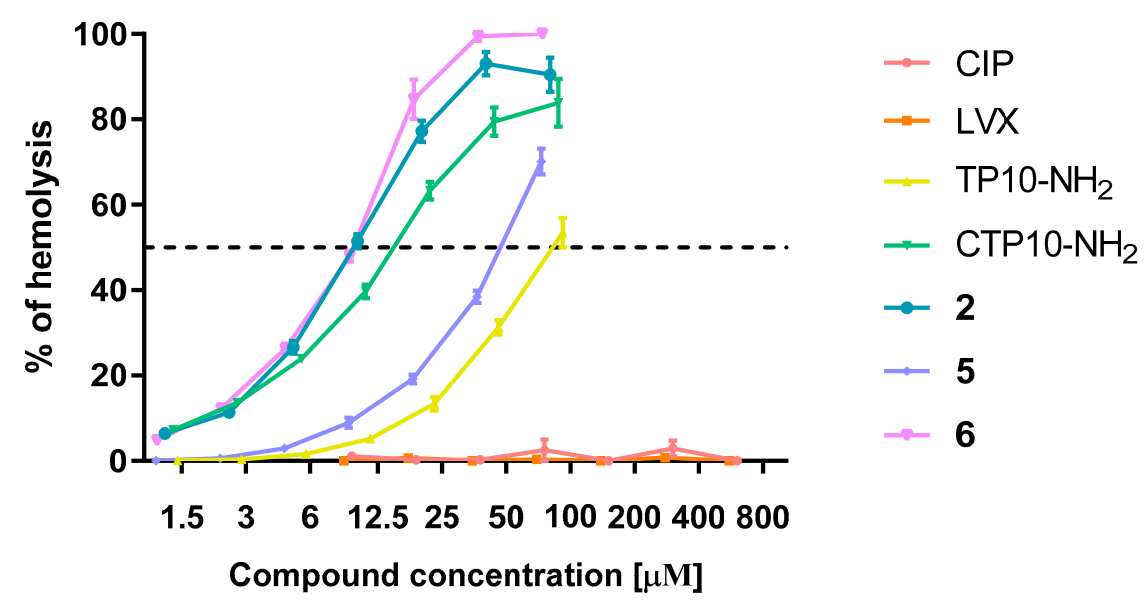

Figure 9. The hemolytic activity of the selected conjugates and their constituents.
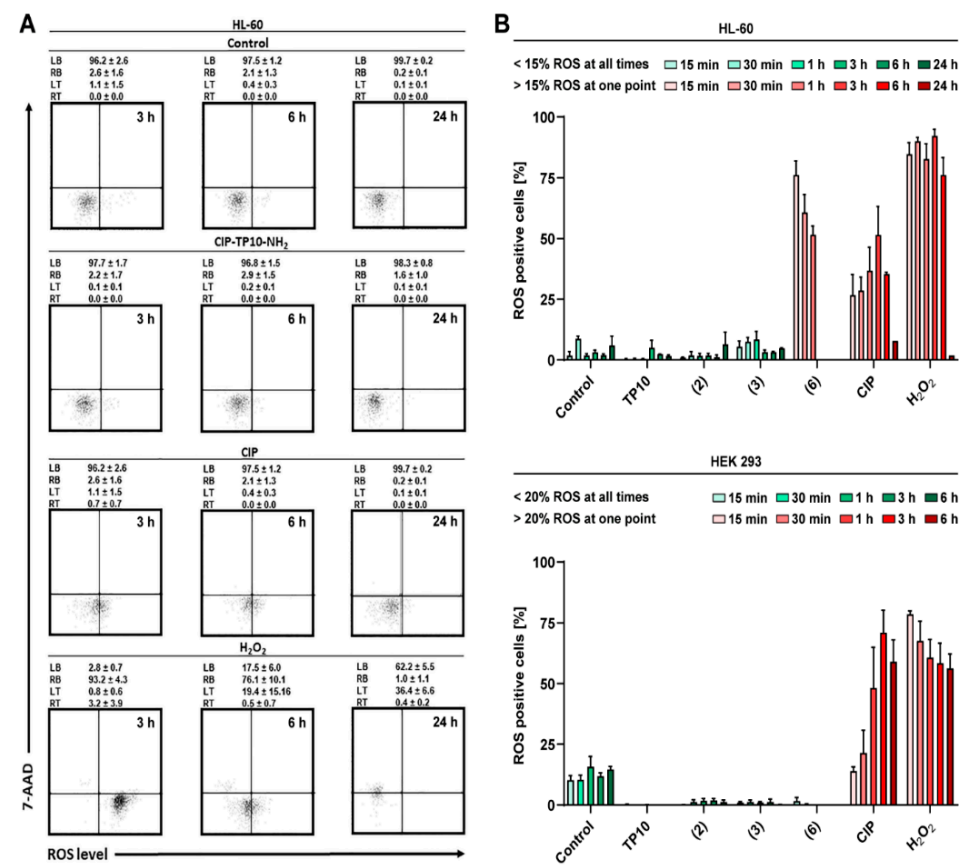

Figure 10. Reactive oxygen species (ROS) generation activity of TP10-NH2 and selected conjugates. (A) Dot plot representation of selected data. Cells were counterstained with 7-AAD as membrane integrity marker. (B) Comparison of the ROS generating effect on two cell lines. The values shown are means $\pm \mathrm{SD}(n=5)$.

\subsection{Selectivity in Relation to Mammalian Cells}

\subsubsection{Antibacterial}

The bacteriostatic selectivity index (BSI) values were calculated (BSI $=\mathrm{IC}_{50} / \mathrm{MIC}_{90}$ or $\mathrm{MHC}_{50} / \mathrm{MIC}_{90}$ ) and are presented in Table S5. For the majority of the tested compounds, BSI values were positive $(>1)$ ranging from 1.2 to 662.8 . Conjugate 3 exhibited exceptionally high BSI values for E. coli, averaging at 534.3. Even though the hemolytic activity of the conjugates was increased compared to bare fluoroquinolones, the related selectivity index values of the conjugates were still favourable.

Additionally, the bactericidal selectivity index $(\mathrm{BcSI})$ values were calculated $\left(\mathrm{BcSI}=\mathrm{IC}_{50} / \mathrm{MBC}\right.$ or $\mathrm{MHC}_{50} / \mathrm{MBC}$ ) and are presented in Table S6. Analogous to the BSI values, for the majority of the tested 
compounds, the BcSI values were positive (>1), ranging from 2.0 to 16.8. Particularly, the selectivity index values related to the hemolytic activity of the conjugate 5 were still positive.

\subsubsection{Antifungal}

Positive mycostatic selectivity index values $\left(\mathrm{MSI}=\mathrm{IC}_{50} / \mathrm{MIC}_{90}\right.$ or $\left.\mathrm{MHC}_{50} / \mathrm{MIC}_{90}\right)$ were obtained for conjugate 5, ranging from 1.2 to 4.4 (Table S7). The highest MSI values were noted for Saccharomyces cerevisiae and Candida albicans.

\subsection{Summary}

The results from all performed experiments were summarised in the form of a table (Table 4). With selectivity both for bacteria and yeast cells and no ROS generation activity, the conjugate 5 possesses the most favourable properties of all synthesised conjugates.

Table 4. Summary data of TP10- $\mathrm{NH}_{2}$ and its conjugates' antimicrobial activity, mammalian toxicity, and molecular interactions.

\begin{tabular}{|c|c|c|c|c|c|c|}
\hline & \multicolumn{6}{|c|}{ Antimicrobial Activity } \\
\hline & \multicolumn{2}{|c|}{ Antibacterial Selectivity } & \multicolumn{4}{|c|}{ Antifungal Selectivity } \\
\hline \multirow{3}{*}{ Compound } & HEK 293 & HEK 293 & HEK 293 & HEK 293 & HEK 293 & HEK 293 \\
\hline & LLC-PK1 & LLC-PK1 & LLC-PK1 & LLC-PK1 & LLC-PK1 & LLC-PK1 \\
\hline & $\begin{array}{c}\text { for } \\
\text { E. coli }\end{array}$ & $\begin{array}{c}\text { for } \\
\text { Gram }+\end{array}$ & $\begin{array}{c}\text { for } \\
\text { C. albicans }\end{array}$ & $\begin{array}{l}\quad \stackrel{\text { for }}{\text { C. } k r u s e i}\end{array}$ & $\begin{array}{c}\text { for } \\
\Delta \text { C. albicans }\end{array}$ & $\begin{array}{l}\text { for } \\
\text { C. glabrata }\end{array}$ \\
\hline & & & & & & \\
\hline TP10-NH 2 & ++ & ++ & - & - & - & - \\
\hline 1 & - & + & - & - & - & - \\
\hline 2 & ++ & ++ & - & - & + & - \\
\hline 3 & ++ & ++ & - & - & - & - \\
\hline 4 & ++ & ++ & - & - & - & - \\
\hline 5 & ++ & ++ & + & + & + & - \\
\hline \multirow[t]{4}{*}{6} & - & + & - & + & - & - \\
\hline & \multicolumn{6}{|c|}{ Mammalian Toxicity } \\
\hline & \multicolumn{2}{|c|}{ ROS } & \multicolumn{4}{|c|}{ Hemolysis Selectivity } \\
\hline & HL-60 & HEK 293 & \multicolumn{2}{|c|}{ HL-60 } & \multicolumn{2}{|c|}{ HEK 293} \\
\hline $\mathrm{TP} 10-\mathrm{NH}_{2}$ & ++ & ++ & \multicolumn{2}{|c|}{-} & \multicolumn{2}{|c|}{-} \\
\hline CTP10- $\mathrm{NH}_{2}$ & $\mathrm{~N} / \mathrm{D}$ & $\mathrm{N} / \mathrm{D}$ & \multicolumn{2}{|c|}{+} & \multicolumn{2}{|c|}{++} \\
\hline 2 & ++ & ++ & \multicolumn{2}{|c|}{+} & \multicolumn{2}{|c|}{+} \\
\hline 3 & + & ++ & \multicolumn{2}{|c|}{ N/D } & \multicolumn{2}{|c|}{ - } \\
\hline 4 & + & ++ & \multicolumn{2}{|c|}{$\mathrm{N} / \mathrm{D}$} & \multicolumn{2}{|c|}{-} \\
\hline 5 & ++ & ++ & \multicolumn{2}{|c|}{-} & \multicolumn{2}{|c|}{+} \\
\hline \multirow[t]{5}{*}{6} & - & ++ & & & & \\
\hline & \multicolumn{6}{|c|}{ Molecular Interactions } \\
\hline & & & \multicolumn{4}{|c|}{ Cellular Uptake } \\
\hline & \multirow{2}{*}{\multicolumn{2}{|c|}{ Topoisomerase II Inhibition }} & \multicolumn{2}{|c|}{ Bacterial } & \multicolumn{2}{|c|}{ Fungal } \\
\hline & & & Gram - & Gram + & $\begin{array}{l}\text { C. albicans } \\
\text { Wall }\end{array}$ & $\begin{array}{c}\text { C. glabrata } \\
\text { Nucleus }\end{array}$ \\
\hline $\mathrm{TP} 10-\mathrm{NH}_{2}$ & \multicolumn{2}{|c|}{$\mathrm{N} / \mathrm{D}$} & $\mathrm{N} / \mathrm{D}$ & $\mathrm{N} / \mathrm{D}$ & + & - \\
\hline 3 & \multirow{2}{*}{\multicolumn{2}{|c|}{$\begin{array}{c}+ \\
++\end{array}$}} & ++ & + & $\mathrm{N} / \mathrm{D}$ & $\mathrm{N} / \mathrm{D}$ \\
\hline 4 & & & ++ & + & N/D & N/D \\
\hline 5 & & & ++ & + & $\mathrm{N} / \mathrm{D}$ & $\mathrm{N} / \mathrm{D}$ \\
\hline 7 & & & $\mathrm{~N} / \mathrm{D}$ & $\mathrm{N} / \mathrm{D}$ & + & - \\
\hline
\end{tabular}

Antimicrobial Activity: ++ SI > 10, + SI > 1; Cellular Uptake ++ within $10 \mathrm{~min},+$ within $1 \mathrm{~h} ;-$ not detected within $2 \mathrm{~h}$; Topoisomerase inhibition $++\mathrm{IC}_{50}<10 \mu \mathrm{M}$, $+\mathrm{IC}_{50}<50 \mu \mathrm{M}$; SI $++\mathrm{SI}>4,+\mathrm{SI}>1$; ROS $++<10 \%$ positive cells in $24 \mathrm{~h},+<15 \%$ positive cells in $24 \mathrm{~h}$; N/D not determined. 


\section{Materials and Methods}

\subsection{Solid-Phase Peptide Synthesis (SPPS)}

Peptides were synthesised by a solid-phase approach using the Fmoc/Boc ${ }^{t}$ chemistry at $50 \mu$ mole scale, applying a Prelude peptide synthesiser (Gyros Protein Technology, Inc., USA). A TentaGel S RAM resin (substitution 0.24 meq/g, Rapp Polymere, Germany) was used as a solid support, yielding, after cleavage, peptides with amide on their $C$-termini. Peptide chains were elongated in the consecutive cycles of deprotection and coupling. Deprotection was performed with $20 \%$ piperidine in $N, N$-dimethylformamide (DMF) and the peptide chain elongation was affected using a reaction mixture composed of $N, N, N^{\prime}, N^{\prime}$-tetramethyl-O-(benzotriazol-1-yl)uroniumtetrafluoroborate (TBTU), 1-hydroxybenzotriazole (HOBt), $N$-methylmorpholine (NMM), and a three-fold molar excess of each $N-\alpha$-Fmoc protected amino acid derivative (GL Biochem, Shanghai, China). After completing the synthesis, peptides were cleaved from the resin and the protecting groups were removed in a one-step procedure using a mixture of TFA:phenol:triisopropylsilane: $\mathrm{H}_{2} \mathrm{O}(88: 5: 2: 5, \mathrm{v} / \mathrm{v} / \mathrm{v} / \mathrm{v})$. The crude peptides were purified on Beckman Gold System (Beckman, Miami, FL, USA) equipped with an RP Supelco Discovery BIO, Wide Pore C $8,10 \mathrm{~mm}$ column $(10 \times 250 \mathrm{~mm}$, Sigma Aldrich, St. Louis, MO, USA) or by PLC 2050 Gilson HPLC with Gilson Glider Prep. Software (Gilson, France), equipped with Grace Vydac C18 (218TP) HPLC column $(22 \times 250$ mm, $10 \mu \mathrm{m}, 300 \AA$, Resolution Systems). The solvent systems were $0.1 \%$ trifluoroacetic acid (TFA) in water (A) and $0.1 \%$ TFA in $80 \%$ acetonitrile in water (B). Different linear gradients were applied (flow rate 5.6 or $20 \mathrm{mLmin}^{-1}$, monitored at $226 \mathrm{~nm}$ ). The purities of the synthesised peptides were checked with an HPLC Pro Star system (Varian, Australia) and use of

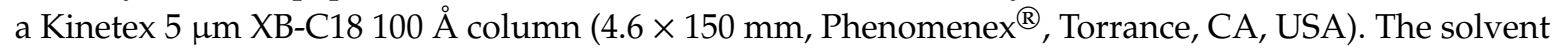
system was as described above. A linear gradient from $10 \%$ to $90 \%$ B for $40 \mathrm{~min}$, flow rate $1 \mathrm{mLmin}^{-1}$, monitored at $226 \mathrm{~nm}$ was used. All described peptides had purities of at least $95 \%$. In order to confirm the correctness of the molecular masses of the synthesised peptides, mass spectrometry analysis was carried out by a MALDI-TOF/TOF, Autoflex MAX spectrometer, (Bruker, Billerica, MA, USA) with an $\alpha$-cyano-4-hydroxycinnamic acid (CCA) and/or 2,5-dihydroxybenzoic acid (DHB) matrix.

\subsection{Synthesis of Levofloxacin and Ciprofloxacin-Based Conjugates}

In the case of CIP-TP10-NH $\mathrm{N}_{2}$ (2) and LVX-TP10-NH $\mathrm{N}_{2}$ (4), Boc-CIP (obtained by the reaction of CIP with di-tert-butyldicarbonate in the presence of $\mathrm{NaOH}$ ) and LVX were manually attached to the peptidyl-resin. An equimolar mixture of $N, N^{\prime}$-diisopropylcarbodiimide (DIPCI), $N, N^{\prime}$-diisopropylethylamine, and LVX or Boc-CIP (3 equiv. each) were dissolved in DMF/DCM (v/v; $1 / 1$ ) and added to the SPPS vessel with peptidyl-resin and allowed to stir for $90 \mathrm{~min}$. The procedure was repeated until the chloranil test gave a negative result. In order to obtain CIP- $\mathrm{CH}_{2} \mathrm{CO}-\mathrm{TP} 10-\mathrm{NH}_{2}(\mathbf{1})$, ciprofloxacin was coupled to the peptide via the submonomeric approach as described previously [36]. After assembling the peptide chain and the removal of the Fmoc group, bromoacetic acid (5 equiv.) was attached to the peptidyl-resin using DIPCI (5 equiv.) in DMF. The procedure was repeated twice. Next, 1.5 equiv. of both ciprofloxacin and triethylamine in DCM/DMF was used to attach the constituent antimicrobial. The reaction mixture was stirring for $24 \mathrm{~h}$ at room temperature. In the case of CIP-S-S-TP10- $\mathrm{NH}_{2}$ (3), a solution of Lomant's reagent (3,3'-dithiodipropionic acid di(N-hydroxysuccinimide ester))-DSP (1.2 equiv.) was dissolved in DMF, added to the SPPS vessel with peptidyl resin, and shaken overnight. The procedure was repeated twice. Ciprofloxacin and triethylamine (1.5 equiv. each) were dissolved in DMF/DCM and added to peptidyl-resin with coupled DSP. The reaction mixture was stirred for another $24 \mathrm{~h}$ at room temperature. All conjugates were detached from the solid support together with the removal of side-chain protection groups and purified as described above. To obtain LVXC-S-S-CTP10- $\mathrm{NH}_{2}$ (5), the disulfide bridge between LVX-Cys (described below in Section 3.2.1) and CTP10- $\mathrm{NH}_{2}$ was formed. Briefly, CTP10- $\mathrm{NH}_{2}$ (46 mg, $0.02 \mathrm{mmol}$ ) was dissolved in $5 \mathrm{~mL}$ of DMF and LVX-Cys(Npys) $(12 \mathrm{mg}, 0.02 \mathrm{mmol})$ was added. The mixture was stirred for $4 \mathrm{~h}$ at room temperature. The reaction was monitored by analytical HPLC. After 4 
$\mathrm{h}$, the solvent was removed in vacuo, and the conjugate was purified by semi-preparative HPLC; yield 20\%; the product was characterised by HPLC and MALDI-TOF MS.

In the case of CIPC-S-S-CTP10- $\mathrm{NH}_{2}(\mathbf{6})$, the disulfide bridge was formed during the reaction of CTP10- $\mathrm{NH}_{2}$ and Cys(Npys)-CIP (see below Section 3.2.2.) as described above for 5 . The total yield was $19 \%$. The product was characterised by HPLC and MALDI-TOF MS.

\subsubsection{Synthesis of LVX-Cys(Npys)}

LVX-Cys(Npys) was obtained in two steps. Firstly, levofloxacin- $N$-hydroxysuccinimidyl ester (LVX-NHS) was synthesised. The esterification reaction between the carboxylic group of LVX (119 mg, $0.33 \mathrm{mmol}$ ) and the hydroxyl group of $N$-hydroxysuccinimide $(38 \mathrm{mg}, 0.33 \mathrm{mmol}$ ) was carried out using $N, N^{\prime}$-dicyclohexylcarbodiimide (DCC, $\left.68 \mathrm{mg}, 0.33 \mathrm{mmol}\right)$ in DMF $(6 \mathrm{~mL})$. The solution was stirred overnight, and then DMF was evaporated under vacuum. The obtained residue was extracted with $10 \mathrm{~mL}$ of ethyl acetate and washed five times with water $(5 \mathrm{~mL}$, portion each time) and twice with ice-cold saturated $\mathrm{NaHCO}_{3}(5 \mathrm{~mL})$. Then, the washed extract was concentrated under vacuum and left overnight to crystallise at room temperature. The product isolated by recrystallisation in EtOH gave LVX-NHS in a 65\% yield. In the next step, Cys(Npys) $(34 \mathrm{mg}, 0.12 \mathrm{mmol}$ ) and DIPEA ( $21 \mu \mathrm{L}$, $0.12 \mathrm{mmol}$ ) dissolved in $5 \mathrm{~mL}$ of DMF were added to the solution of LVX-NHS (55 mg, $0.12 \mathrm{mmol}$ ) ( $\mathrm{pH}$ was adjusted to 8-9 by $\mathrm{NaOH}$ ). The reaction mixture was stirred overnight. The solvent was removed in vacuo and the product was treated several times with ether to wash out the unreacted ester. The remaining material was dissolved in water and lyophilised (yield 83\%, $89 \mathrm{mg}$ ).

\subsubsection{Synthesis of Cys(Npys)-CIP}

Boc-Cys(Npys)-OSu was obtained in the reaction of Boc-Cys(Npys)-OH with $\mathrm{N}$-hydroxysuccinimide in the presence of $N, N^{\prime}$-dicyclohexylcarbodiimide (DCC) as the coupling reagent (see above). In the next step, CIP $(66 \mathrm{mg}, 0.2 \mathrm{mmol})$ in $5 \mathrm{~mL}$ of DMF/DCM $(3 / 2 ; \mathrm{v} / \mathrm{v})$ was added to the solution of Boc-Cys(Npys)-OSu (94 mg, $0.2 \mathrm{mmol}$ ) in $3 \mathrm{~mL}$ of DMF. The reaction mixture was stirred overnight. The solvent was removed in vacuo, and the product was treated several times with ether (containing $10 \%$ DCM) to wash out the unreacted ester. The Boc-protecting group was removed by TFA ( $5 \mathrm{~mL}$, $15 \mathrm{~min}$ at room temperature). The solution was concentrated in vacuo, and then the remaining material was dissolved in water and lyophilised (yield $92 \%, 128 \mathrm{mg}$ ).

Synthesis of fluorescently labelled compounds

In order to obtain fluorescein-labelled ciprofloxacin, 5(6)-carboxyfluorescein $\mathrm{N}$-succinimidyl ester was prepared. The solution of 5(6)-carboxyfluorescein and $N$-hydroxysuccinimide $(0.2 \mathrm{mmol}$ each) was stirred in the presence of $N, N^{\prime}$-dicyclohexylcarbodiimide $(0.2 \mathrm{mmol})$ in DMF/DCM, first for $15 \mathrm{~min}$ at $0{ }^{\circ} \mathrm{C}$ and then for $3 \mathrm{~h}$ at RT. In the next step, solvents were evaporated in vacuo, and the residue was crystallised from methanol. The yellowish precipitate was drained over reduced pressure and washed with methanol (yield 76\%). Then, 5(6)-carboxyfluorescein $\mathrm{N}$-succinimidyl ester and ciprofloxacin (0.05 mmol each) were suspended in DMF/DCM and allowed to stir overnight. The yellow precipitate was filtrated over reduced pressure, suspended in water, lyophilised, and analysed as described above (yield 87\%).

\subsection{Synthesis of Fluorescently Labelled Compounds}

In order to attach fluoresceine $(C f)$ to TP10- $\mathrm{NH}_{2}$, an analogue of TP10- $\mathrm{NH}_{2}$ containing Lys(Mtt) (Mtt stands for 4-methyltrityl) in position 12 instead of Ala was synthesised on a solid phase. After completing the synthesis, the Mtt protection of an $\varepsilon$-amino group of Lys was removed by 3-min incubations in 1.8\% TFA in DCM until reaction completion, indicated by the disappearance of the yellow color (Mtt cation) in the drained deprotection solution. Then, the fluorophore was attached manually using 3 equiv. of 5(6)-carboxyfluorescein (Novabiochem, Merck, Darmstadt, Germany), HATU, HOAt, and DIPEA (molar ratio 1:1:1:2). The procedure was repeated three times. Next, TP10 $(C f)-\mathrm{NH}_{2}$ was cleaved from half of the peptidyl-resin, and the crude peptide was purified as described above. 
The other half of the peptidyl-resin was used to obtain the labelled CIP-CH ${ }_{2} \mathrm{CO}-\mathrm{TP} 10(C f)-\mathrm{NH}_{2}(7)$. The synthesis was performed by manual attachment of bromoacetic acid to the peptidyl-resin, and then CIP was coupled via the sub-monomeric approach. Finally, the labelled conjugate was removed from the solid support. The crude product was purified by semi-preparative HPLC, and characterised by HPLC and MS analysis.

\subsection{Microorganism Strains and Growth Conditions}

The following strains were used for antimicrobial activity tests: C. albicans ATCC 10231, C. albicans

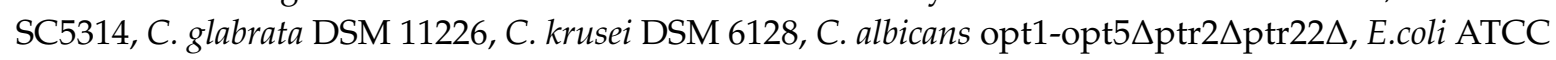
25922, P. aeruginosa ATCC 27853, S. aureus ATCC 29213, and S. epidermidis ATCC 12228. C. albicans Gu4, and Gu5 clinical isolates [26] were gifts from Joachim Morschhäuser, Würzburg, Germany. The yeast strains were maintained on YPD agar plates $(1 \%(w / v)$ yeast extract, $2 \%(w / v)$ peptone, $2 \%(w / v)$ glucose, $\%(w / v)$ agar) in $30{ }^{\circ} \mathrm{C}$ and bacterial strains on LA (Luria-Bertani agar; $1 \%(w / v)$ tryptone, $1 \%(w / v)$ $\mathrm{NaCl}, 0 . \%(w / v)$ yeast extract, $2 \%$ agar) plates in $37^{\circ} \mathrm{C}$ for $16-24 \mathrm{~h}$.

\subsection{Stability Testing}

Cell culture of $S$. aureus ATCC 25,923 was refreshed on solid LA overnight $\left(37^{\circ} \mathrm{C}\right)$. The next day, cell suspensions were prepared in LB liquid medium, and after about 2 to $3 \mathrm{~h}$ (logarithmic growth phase), CIP-S-S-TP10-NH2 (3) was added at concentrations of $16 \mu \mathrm{gmL}^{-1}$ in a volume of $1 \mathrm{~mL}$. The cultures were continued overnight $\left(37^{\circ} \mathrm{C}, 180 \mathrm{rpm}\right)$. The next day, $1 \mathrm{~mL}$ of cell cultures was transferred to 2-mL tubes and centrifuged $\left(12,000 \mathrm{rpm}, 1 \mathrm{~min}, 4^{\circ} \mathrm{C}\right.$ ) (from this moment, the samples were kept on ice). The supernatant was discarded and the pellet was suspended in $0.5 \mathrm{~mL}$ of PBS. Zirconia beads (A\&A Biotechnology, Gdynia, Poland) and $350 \mu \mathrm{L}$ of lysis buffer (Bioline) were added to the samples. The tubes were shaken on a BeadBeater device to break the cell wall $(3 \times 20 \mathrm{~s})$. The suspension was transferred to new tubes and $8.5 \mu \mathrm{L}$ of Protease Inhibitor Cocktail $(100 \times$ concentrated, Fermentas, Waltham, MA, USA) was added. The tubes were centrifuged $\left(12,000 \mathrm{rpm}, 20 \mathrm{~min}, 4^{\circ} \mathrm{C}\right)$. The supernatant was transferred to new tubes and stored at $-20^{\circ} \mathrm{C}$ until the LC-MS analysis. Before MS analyses, the samples were desalted using ZipTip ${ }^{\circledR}$ C18 Pipette Tips (Merck Millipore Ltd., Burlington, MA, USA) according to the manufacturer's protocol. LC-MS experiments were performed on a Qtof lcms9030 spectrometer (Shimadzu, Japan) equipped with an electropress ion source, LC Nexera X2 module with autosampler. Samples were dissolved in water and analysed on an XB C18 Aeris Peptide column (Phenomenex) o $(100 \mathrm{~mm} \times 2.1 \mathrm{~mm}) ; 3.6 \mu \mathrm{m}$ bead diameter. The LC system was operated with mobile phase: solvent A: $0.1 \%$ formic acid in $\mathrm{H}_{2} \mathrm{O}$ and solvent B: $0.1 \%$ formic acid in MeCN. Samples were separated with a linear gradient (optimised for the best separation of the analysed samples), maintained at a flow rate of $0.2 \mathrm{mLmin}^{-1}$. The injection volume was between 0.1 and $0.5 \mu \mathrm{L}$.

\subsection{Antibacterial Activity Assay}

The antibacterial activity (bacteriostatic: MIC and bactericidal: MBC) of the tested compounds was determined in MHB (Mueller Hinton Broth, Sigma Aldrich, St. Louis, MO, USA) using a serial two-fold dilution method in 96-well microtiter plates according to CLSI recommendations, described in M07-A10 document. The exact conditions have been described previously [9]. All experiments were performed in three replicates. The $\mathrm{MIC}_{90}$ and $\mathrm{MIC}_{50}$ values were defined as the concentrations of compounds tested that caused a $90 \%$ or $50 \%$ reduction of growth, respectively, comparing to the drug-free control.

\subsection{Determination of Resistance Induction Potential}

E. coli ATCC 25,922 or S. aureus ATCC 29,213 cells were taken from $-80^{\circ} \mathrm{C}$ and freshly grown on Mueller Hinton Agar (MHA) plates. The MIC values for CIP and CIP-S-S-TP10-NH 2 (3) were determined. The cells $\left(10^{8} \mathrm{CFU}\right)$ were grown on MHA plates containing one of the tested compounds at several concentrations equal or slightly higher than the MIC values determined as described in 
Section 2.7. The highest concentration at which the cells were able to grow (MIC-10 ${ }^{8}$ ) was selected for the rest of the experiment. Cells $\left(10^{8}\right.$ cells per plate) were incubated on MHA plates in the presence or absence (control) of the tested compound at MIC- $10^{8}$ and passaged 10 times at 1- to 3-day intervals. MHA plates with the addition of the tested compound were freshly prepared every time before the passage. After the 5th and the 10th passage, cells from colonies grown on the plates were collected for determination of MIC values.

\subsection{Antifungal Activity Assay}

The antifungal activity of the tested compounds was assessed in 96-well microtiter plates, in buffered RPMI-1640 medium according to the CLSI recommendations (M27-A3 document, Clinical Laboratory Standards Institute 2008). The lowest concentration that prevented the growth of microorganisms was assigned as MIC, while the lowest drug concentration that caused $90 \%$ or $50 \%$ inhibition of growth compared to the drug-free control was assigned as $\mathrm{MIC}_{50}$ and $\mathrm{MIC}_{50}$, respectively. All experiments were performed in three replicates.

\subsection{Cytotoxicity Assay}

Cytotoxicity was assessed against three mammalian cell lines: LLC-PK1, Hep G2, and HEK 293. Multiwell (96-well) plates were seeded at 7000 cells/well in Medium 199 supplemented with 7.5\% FBS, MEM Eagle's medium supplemented with $10 \%$ FBS, or DMEM medium supplemented with $10 \%$ FBS, respectively. All media were supplemented with L-glutamine and antibiotics (penicillin/streptomycin). Cells were allowed to attach overnight. Drugs were dissolved in cell culture medium and added to wells in $100-\mu \mathrm{L}$ aliquots of $2 \times$ concentrated solutions, in triplicates. To control wells, $100 \mu \mathrm{L}$ of the medium were added. Cells were incubated with the studied compounds for $72 \mathrm{~h}$ at $37^{\circ} \mathrm{C}$ and $95 \% / 5 \%$ or $90 \% / 10 \%$ (HEK 293 cells) $\mathrm{CO}_{2}$ atmosphere. Then, $20-\mu \mathrm{L}$ aliquots of MTT solution in PBS $(4 \mathrm{mg} / \mathrm{mL}$ ) were added to all wells and plates were incubated further for $3 \mathrm{~h}$ in $37^{\circ} \mathrm{C}$. Formazan crystals formed were dissolved in $100 \mu \mathrm{L}$ of DMSO and the absorbance of the solutions was measured using a multiwell plate reader (Spark, Tecan, Männedorf, Switzerland) at $\lambda=540 \mathrm{~nm}$. Cytotoxicity was determined compared to the drug-free control. All experiments were performed in triplicates.

\subsection{Measurement of ROS Generation}

ROS generation activity was evaluated as described previously [37]. Briefly, HEK 293 cells were seeded on 35-mm Petri dishes in the amount of 15,000 cells per plate for $24 \mathrm{~h}$ in DMEM medium. Compounds were added at final concentrations: CIP-TP10- $\mathrm{NH}_{2}(2) 5 \mu \mathrm{M}$, and CIP $500 \mu \mathrm{M}$. HL-60 cells were seeded on 35-mm Petri dishes in the amount of 25,000 cells/5 mL in RPMI 1640 medium and compounds were added at final concentrations: CIP-TP10- $\mathrm{NH}_{2}$ (2) $2.5 \mu \mathrm{M}$, and CIP $100 \mu \mathrm{M}$. Positive controls contained $250 \mu \mathrm{M} \mathrm{H}_{2} \mathrm{O}_{2}$, while negative controls were without any additions. After $0.5,2.5,5.5$, and $24 \mathrm{~h}$ of incubation at $37^{\circ} \mathrm{C}$, the CM-H2DCFDA molecular probe (Thermo Fischer Scientific, Waltham, USA) was added to the plates and incubation was continued for another $0.5 \mathrm{~h}$. The HEK 293 cells were detached with 0.05\% trypsin solution in PBS and HBSS (Hank's Balanced Salt Solution) and suspended in fresh DMEM medium. All samples were additionally stained with 7-AAD (7-aminoactinomycin D, $0.8 \mu \mathrm{g} / \mathrm{mL}$ ) and immediately analysed with a Guava easyCyte flow cytometer (Merc, Burlington, USA). The determinations were performed in triplicates.

\subsection{Determination of the Haemolytic Potential}

Blood samples were kindly provided by the Regional Center for Blood Donation and Blood Treatment in Gdańsk. Erythrocytes were prepared as described previously [38]. The hemolysis assays were performed in 96-well plates. The tested compounds were serially diluted in PBS in the concentration range $200-3.125 \mu \mathrm{g} / \mathrm{mL}$ and $100-\mu \mathrm{L}$ aliquots were poured into wells. $1 \%$ Triton X-100 solution, $100 \mu \mathrm{L}$, was used as a positive control and $100 \mu \mathrm{L}$ of the PBS solution served as a negative control. Erythrocyte suspensions in PBS $(100 \mu \mathrm{L})$ were added to the wells, and plates were incubated 
at $37^{\circ} \mathrm{C}$ for $1 \mathrm{~h}$ and then centrifuged $(500 \times g, 5 \mathrm{~min})$. Supernatants collected $(100 \mu \mathrm{L})$ were transferred to new microtitration plates. Absorbance at each well was measured at $540 \mathrm{~nm}$. All experiments were performed in biological triplicates.

\subsection{Monitoring of the Cellular Uptake}

Overnight cultures of C. albicans ATCC 10,231 cells in YBG medium were centrifuged at $5000 \mathrm{rpm}$ for $3 \mathrm{~min}$, and the cells were rinsed with phosphate-buffered saline (PBS). Cells were suspended in PBS and incubated with fluorescein-labelled CIP, TP10- $\mathrm{NH}_{2}$, or conjugate (7) $(20 \mu \mathrm{g} / \mathrm{mL})$ at $30{ }^{\circ} \mathrm{C}$ for $15 \mathrm{~min}$. If appropriate, one drop of nuclear-staining dye Hoechst 33,342 solution $(1 \mu \mathrm{g} / \mathrm{mL})$ was added to the sample. Cell suspensions were centrifuged (5000 rpm, $3 \mathrm{~min}$, room temperature), rinsed three times with PBS buffer, and cells were suspended in PBS buffer. Cellular fluorescence was visualised using a lens $63 \times$, at $\lambda_{\mathrm{ex}} / \lambda_{\mathrm{em}}=485 \mathrm{~nm} / 520 \mathrm{~nm}$ for fluorescein and $\lambda_{\mathrm{ex}} / \lambda_{\mathrm{em}}=350 \mathrm{~nm} / 461 \mathrm{~nm}$ for Hoechst 33342, using an Olympus BX60 epifluorescence microscope (Olympus, Tokyo, Japan) or LSM 800 T-PMT confocal microscope (Carl Zeiss AG, Oberkochen, Germany) with a CCD camera. Images were acquired and processed with ZEN Blue software.

\subsection{Inhibition of DNA Relaxation Mediated by DNA Topoisomerase II}

A yeast DNA topoisomerase II Relaxation Assay Kit was purchased from Inspiralis (Norwich, UK) and assays were performed according to the manufacturer's procedure. Briefly, the reaction mixture contained $500 \mathrm{ng}$ of pBR322 DNA in reaction buffer $(10 \mathrm{mM}$ Tris- $\mathrm{HCl}, \mathrm{pH} 7.9,5 \mathrm{mM} \mathrm{MgCl} 2,100 \mathrm{mM}$ $\mathrm{KCl}, 2 \%(v / v)$ glycerol, $1 \mathrm{mM} \mathrm{ATP})$ as well as the studied compounds dissolved and diluted in dd $\mathrm{H}_{2} \mathrm{O}$ at the indicated concentrations. The reaction was initiated by the addition of topoisomerase II and allowed to proceed at $30{ }^{\circ} \mathrm{C}$ for $30 \mathrm{~min}$. Reactions were terminated by the addition of $5 \mu \mathrm{L}$ of the loading buffer (NEB; \#B7024). The studied compounds were extracted from the reaction mixtures on vortex (for $30 \mathrm{~s}$ ) with $30 \mu \mathrm{L}$ of chloroform/isoamyl alcohol solution $(24: 1 ; v / v)$. After centrifugation ( $3 \mathrm{~min}, 20,000 \times \mathrm{g}$ ), half of the upper aqueous phases were separated in $1 \%$ agarose gels at $90 \mathrm{~V}$ for $4 \mathrm{~h}$ in TBE buffer (90 mM Tris-base, $70 \mathrm{mM}$ boric acid, $1 \mathrm{mM}$ EDTA, pH 8). Gels were stained with $1 \mu \mathrm{g} / \mathrm{mL}$ ethidium bromide (EtBr) for 15 min to visualise DNA and unbound EtBr was removed by washing gel in $1 \mathrm{mM} \mathrm{MgSO}_{4}$ solution in dd $\mathrm{H}_{2} \mathrm{O}$ for $15 \mathrm{~min}$. Gels were photographed under UV illumination with a ESSENTIAL V6 (UVITEC, Cambridge, UK).

\subsection{Bacterial Viability Assay}

Overnight bacteria cultures at $37^{\circ} \mathrm{C}$ were diluted and grown up to $\mathrm{OD}_{600} 0.2$. Cultures were centrifuged at $7000 \mathrm{rpm}$ for $3 \mathrm{~min}$, and the cells were washed with $0.9 \% \mathrm{NaCl}$ and suspended in $0.9 \%$ $\mathrm{NaCl}$. The tested compound was added at a concentration equal to the MBC value. Equal aliquots of $3.34 \mathrm{mM}$ Syto 9 and $20 \mathrm{mM}$ propidium iodide were mixed, and $1 \mu \mathrm{L}$ was added to $300 \mu \mathrm{L}$ of cell suspension. Then, $3-5 \mu \mathrm{L}$ of the samples were spotted on $0.8 \%$ agarose pads in $0.9 \% \mathrm{NaCl}$. Microphotographs were acquired using a Zeiss Axio Observer microscope with a CCD camera. Images were processed in ZEN Blue 2.6 software.

\section{Conclusions}

Conjugation of CIP and LVX with TP10- $\mathrm{NH}_{2}$ markedly changed the biological properties of these drugs. Particularly, unlike the mother fluoroquinolones, their conjugates with the cell-penetrating peptide exhibited antifungal activity and mammalian cytotoxicity. The latter seems to be at least in part due to the intrinsic cytoplasmic membrane disruption activity of TP10- $\mathrm{NH}_{2}$, which was demonstrated in hemolytic studies. The earlier reports concerning the mammalian cytotoxicity of TP10 were confusing since no toxicity of this CPP against HeLa cells was observed [19]. In contrast, in another study, substantial membrane toxicity (measured by the lactate dehydrogenase leakage) against three cell lines and some hemolytic effect was noted $[29,32,39]$. On the other hand, the antifungal growth inhibitory effect of conjugates observed by us was clearly related to their facilitated uptake by sensitive yeast 
cells. All CIP, LVX, TP10-NH $\mathrm{NH}_{2}$ and their conjugates were found to be inhibitors of yeast type II DNA topoisomerase. CIP and LVX appeared as much weaker inhibitors of this enzyme than their conjugates with TP10- $\mathrm{NH}_{2}$. However, no similar relationship was found for the antifungal activity of cleavable (3, 5 , and 6 , possibly releasing a free drug intracellularly) and non-cleavable $(2,4)$ conjugates. Therefore, topoisomerase II may not be a primary target of these compounds.

Conjugation with TP10- $\mathrm{NH}_{2}$ mostly lowered the antibacterial activity of the fluoroquinolones tested, although in the case of CIP-S-S-TP10- $\mathrm{NH}_{2}$ (3), this effect was negligible. It should be noted, however, that the conjugates 2, 3, and 5 demonstrated a relatively strong growth inhibitory effect against Pseudomonas aeruginosa, i.e., bacterium that appeared completely resistant to $\mathrm{TP} 10-\mathrm{NH}_{2}$.

The antifungal activity and mammalian cytotoxicity of redox-sensitive [10] $\mathbf{3}$ and $\mathbf{5}$ were very similar to that of their redox-resistant analogues 2 and 4 . On the other hand, the activity of cleavable 3 against $S$. epidermidis, P. aeruginosa, and especially against $E$. coli was better than that of non-cleavable 2. It seems, therefore, that intracellular CIP release from its conjugate with $\mathrm{TP} 10-\mathrm{NH}_{2}$ facilitates the interaction of the fluoroquinolone with bacterial gyrase, while in eukaryotic cells, conjugate cleavage is not a prerequisite for effective interaction with a molecular target.

Although the antifungal effect has not been observed for all conjugates and all fungal cell lines, the observed phenomenon is, in our opinion, pretty interesting. Since the antifungal effect was much more robust in conjugates where $\mathrm{TP} 10-\mathrm{NH}_{2}$ was linked to the fluoroquinolone by a disulfide bond, it seems likely that the antifungal activity may be due to the interaction of parental drugs with DNA and nuclear enzymes, following proteolytic cleavage of the conjugate inside the cell. Additionally, the ligand covalently bound with TP10- $\mathrm{NH}_{2}$ may disrupt the membrane [40]. Therefore, the modification of fluoroquinolone's action by linkage with TP10- $\mathrm{NH}_{2}$ is strictly a result of the conjugation. As we were able to show a proof of concept of expanding antibacterial drug action by antifungal activity for clinically established compounds (originally lacking this activity), it suggests a future perspective for the use of cell-penetrating peptides in clinical treatment. Additionally, we found an unusual mechanism of action, including both topoisomerase II inhibition and a membrane effect. Such observations suggest, however, a next step towards acquiring a possible antifungal drug candidate. This is a conjugation of CIP or LVX to a CPP exhibiting optimal parameters of mammalian cell toxicity. Alternatively, it is worth exploring the linking of TP10- $\mathrm{NH}_{2}$ with other antimicrobial drugs.

We were able to show a proof of concept that conjugation of CPP to an established antibacterial drug may result in the expansion of the activity spectrum. In particular, fluoroquinolones CIP and LVX conjugated to TP10- $\mathrm{NH}_{2}$ peptide acquired antifungal activity. Notably, this activity against $C$. albicans and C. krusei was slightly better than that of the known antifungal drug Fluconazole. Moreover, the clinical strain of C. albicans resistant to FLU due to the FLU-induced overexpression of Cdr1p and Cdr2p drug efflux pumps remained sensitive to conjugates 1-6. This finding suggests that the conjugates are not good substrates for Cdr1p and Cdr2p. The cytotoxic potential of the conjugates, while interesting within the scope of anticancer approaches, reduces their potential for a safe use to address non-neoplastic conditions, e.g., fungal (and other microbial) infections. This actually agrees with previous promising reports on $\mathrm{CP}$-drug conjugates. Their vast majority addresses potential anticancer applications, which is probably related to the fact that there is increasing evidence (also supported by this work) on the cytotoxicity and hemolytic activity of most such conjugates.

Interestingly, during our studies, we discovered the antileukemic activity of the studied conjugates (manuscript in preparation). The antileukemic activity added upon antibacterial, as well as novel antifungal activity, may prove advantageous for leukaemia treatment. Specifically, for patients receiving allogeneic blood marrow transplantation (allo-BMT), autologous blood marrow transplantation (auto-BMT), or peripheral blood stem cell transplants (PBSCT)s, bacterial infection remains one of the leading causes of morbidity and mortality (with an incidence ranging from $18.6 \%$ to $43.6 \%$ ) despite early aggressive antimicrobial therapy $[41,42]$. The gold standard therapy regimens consist of either levofloxacin (LVX) or ciprofloxacin (CIP), exhibiting negligible anticancer activity [43-45]. 
Future investigations will be focused on the understanding of the fundamental molecular mechanism of action of the tested conjugates. Currently, we are performing computer simulation studies for selected conjugates to examine their interaction with the cell membrane, including the possibility of aggregation and formation of intra-membrane channels as well as interaction with DNA after proteolysis. We would also like to move to ex vivo studies on patient-derived cell lines.

Supplementary Materials: Supplementary Materials can be found at http://www.mdpi.com/1422-0067/21/13/ 4696/s1.

Author Contributions: Conceptualization, N.P., K.G., K.O., J.L., A.L., S.M. and K.R.; Data curation, N.P., K.G., K.O., M.H., M.S., A.S., D.M., J.L. and A.Ł.; Formal analysis, K.G. and M.H.; Funding acquisition, K.R.; Investigation, N.P., K.G., K.O., M.H., M.S., A.S., D.M., D.D., A.G.-D., J.L., A.Ł. and S.M.; Methodology, N.P., K.G., K.O., M.H., M.S., A.S., D.M., D.D., A.G.-D., J.L. and A.E.; Project administration, S.M. and K.R.; Supervision, A.E., S.M. and K.R.; Validation, N.P., K.G., K.O., M.H., M.S., A.S., D.M., D.D., A.G.-D., J.L. and A.E.; Visualization, N.P., K.G., M.H., M.S., A.S., D.M., J.L. and A.L.; Writing—original draft, K.G., K.O., M.S., D.M., A.Ł., S.M. and K.R.; Writing-review and editing, N.P., K.G., M.H., A.S., D.D., A.G.-D., J.L., A.E., S.M. and K.R. All authors have read and agreed to the published version of the manuscript.

Funding: This work was supported by the National Science Centre (NCN, Poland) under grant No UMO-2016/21/B/ST5/00101.

Conflicts of Interest: The authors declare no conflict of interest.

\section{Abbreviations}

\begin{tabular}{ll} 
AMP & antimicrobial peptide \\
BCSI & Bactericidal Selectivity Index \\
BSI & Bacteriostatic Selectivity Index \\
CCA & - -cyano-4-hydroxycinnamic acid matrix \\
Cf & 5 (6)-carboxyfluorescein \\
CIP & ciprofloksacin \\
CPP & cell-penetrating peptide \\
DCC & N,N'-dicyclohexylcarbodiimide \\
DCM & dichloromethane \\
DHB & 2,5-dihydroxybenzoic acid matrix \\
DIC & Differential Interference Contrast \\
DIPCI & N,N'-diisopropylocarbodiimide \\
DIPEA & N,N-diisopropylethylamine \\
DMF & N,N-dimethylformamide \\
EtBr & ethidium bromide \\
HATU & (1-[bis(dimethylamino)methylene]-1H-1,2,3-triazolo[4,5-b]pyridinium 3-oxide hexafluorophosphate \\
HEK293 & human embryonic kidney cells \\
HeLa & human cervical cancer cells \\
HepG2 & human liver cancer cells \\
HL-60 & human myeloid leukemia cells \\
HOAt & 1-hydroksy-7-azabenzotriazol \\
HOBt & 1-hydroxybenzotriazole \\
IH & Minimum Hemolytic Concentration \\
LLC-PK1 & old male pig kidney cells \\
LVX & levofloxacin \\
LVX-NHS & levofloxacin- $N$-hydroxysuccinimidyl ester \\
MBC & Minimal Bactericidal Concentration \\
MDR & multidrug-resistance \\
MHA & Mueller Hinton Agar \\
MHB & Mueller Hinton Broth \\
MIC & Minimal Inhibitory Concentration \\
MSI & Mycostatic Selectivity Index \\
Mtt & 4-methyltrityl \\
\hline
\end{tabular} 


$\begin{array}{ll}\text { NMM } & N \text {-methylmorpholine } \\ \text { Npys } & \text { Npys } \\ \text { PBS } & \text { phosphate-buffered saline } \\ \text { ROS } & \text { reactive oxygen species } \\ \text { TAT } & \text { trans-activator protein } \\ \text { TBTU } & N, N, N^{\prime}, N^{\prime} \text {-tetramethyl-O-(benzotriazol-1-yl)uroniumtetrafluoroborate } \\ \text { TFA } & \text { trifluoroacetic acid }\end{array}$

\section{References}

1. Ezelarab, H.A.A.; Abbas, S.H.; Hassan, H.A.; Abuo-Rahma, G.E.D.A. Recent updates of fluoroquinolones as antibacterial agents. Arch. Pharm. 2018, 351, e1800141. [CrossRef] [PubMed]

2. WHO Model List of Essential Medicines (19th List); World Health Organization: Geneva, Switzerland, 2015.

3. Hooper, D.C. Mechanisms of Action of Antimicrobials: Focus on Fluoroquinolones. Clin. Infect. Dis. 2001, 32, S9-S15. [CrossRef] [PubMed]

4. $\quad$ Redgrave, L.S.; Sutton, S.B.; Webber, M.A.; Piddock, L.J.V. Fluoroquinolone resistance: Mechanisms, impact on bacteria, and role in evolutionary success. Trends Microbiol. 2014, 22, 438-445. [CrossRef]

5. Ramsey, J.D.; Flynn, N.H. Cell-penetrating peptides transport therapeutics into cells. Pharmacol. Ther. 2015, 154, 78-86. [CrossRef] [PubMed]

6. Samuel, B.U.; Hearn, B.; Mack, D.; Wender, P.; Rothbard, J.; Kirisits, M.J.; Mui, E.; Wernimont, S.; Roberts, C.W.; Muench, S.P.; et al. Delivery of antimicrobials into parasites. Proc. Natl. Acad. Sci. USA 2003, 100, 14281-14286. [CrossRef]

7. Cohen, D.T.; Zhang, C.; Fadzen, C.M.; Mijalis, A.J.; Hie, L.; Johnson, K.D.; Shriver, Z.; Plante, O.; Miller, S.J.; Buchwald, S.L.; et al. A chemoselective strategy for late-stage functionalisation of complex small molecules with polypeptides and proteins. Nat. Chem. 2019, 11, 78-85. [CrossRef]

8. Purkayastha, N.; Capone, S.; Beck, A.K.; Seebach, D.; Leeds, J.; Thompson, K.; Moser, H.E. Antibacterial Activity of Enrofloxacin and Ciprofloxacin Derivatives of $\beta$-Octaarginine. Chem. Biodivers. 2015, 12, 179-193. [CrossRef]

9. Ptaszyńska, N.; Olkiewicz, K.; Okońska, J.; Gucwa, K.; Łęgowska, A.; Gitlin-Domagalska, A.; Dębowski, D.; Lica, J.; Heldt, M.; Milewski, S.; et al. Peptide Conjugates of Lactoferricin Analogues and Antimicrobials-Design, Chemical Synthesis, and Evaluation of Antimicrobial Activity and Mammalian Cytotoxicity. Peptides 2019, 117, 170079. [CrossRef]

10. Ptaszyńska, N.; Gucwa, K.; Olkiewicz, K.; Łȩgowska, A.; Okońska, J.; Ruczyński, J.; Gitlin-Domagalska, A.; Dębowski, D.; Milewski, S.; Rolka, K. Antibiotic-Based Conjugates Containing Antimicrobial HLopt2 Peptide: Design, Synthesis, Antimicrobial and Cytotoxic Activities. ACS Chem. Biol. 2019, 14, 2233-2242. [CrossRef]

11. Stewart, K.M.; Horton, K.L.; Kelley, S.O. Cell-penetrating peptides as delivery vehicles for biology and medicine. Org. Biomol. Chem. 2008, 6, 2242-2255. [CrossRef]

12. Guo, Z.; Peng, H.; Kang, J.; Sun, D. Cell-penetrating peptides: Possible transduction mechanisms and therapeutic applications (review). Biomed. Rep. 2016, 4, 528-534. [CrossRef]

13. Guidotti, G.; Brambilla, L.; Rossi, D. Cell-Penetrating Peptides: From Basic Research to Clinics. Trends Pharmacol. Sci. 2017, 38, 406-424. [CrossRef] [PubMed]

14. Green, M.; Loewenstein, P.M. Autonomous functional domains of chemically synthesised human immunodeficiency virus tat trans-activator protein. Cell 1988, 55, 1179-1188. [CrossRef]

15. Frankel, A.D.; Pabo, C.O. Cellular uptake of the tat protein from human immunodeficiency virus. Cell 1988, 55, 1189-1193. [CrossRef]

16. Agrawal, P.; Bhalla, S.; Usmani, S.S.; Singh, S.; Chaudhary, K.; Raghava, G.P.S.; Gautam, A. CPPsite 2.0: A repository of experimentally validated cell-penetrating peptides. Nucleic Acids Res. 2016, 44, D1098-D1103. [CrossRef] [PubMed]

17. Pooga, M.; Hällbrink, M.; Zorko, M.; Langel, U. Cell penetration by transportan. FASEB J. 1998, 12, 67-77. [CrossRef] [PubMed]

18. Soomets, U.; Lindgren, M.; Gallet, X.; Hällbrink, M.; Elmquist, A.; Balaspiri, L.; Zorko, M.; Pooga, M.; Brasseur, R.; Langel, U. Deletion analogues of transportan. Biochim. Biophys. Acta 2000, 1467, 165-176. [CrossRef] 
19. Nekhotiaeva, N.; Elmquist, A.; Rajarao, G.K.; Hällbrink, M.; Langel, U.; Good, L. Cell entry and antimicrobial properties of eukaryotic cell-penetrating peptides. FASEB J. 2004, 18, 394-396. [CrossRef] [PubMed]

20. Horváti, K.; Bacsa, B.; Mlinkó, T.; Szabó, N.; Hudecz, F.; Zsila, F.; Bősze, S. Comparative analysis of internalisation, haemolytic, cytotoxic and antibacterial effect of membrane-active cationic peptides: Aspects of experimental setup. Amino Acids 2017, 49, 1053-1067. [CrossRef] [PubMed]

21. Bárány-Wallje, E.; Gaur, J.; Lundberg, P.; Langel, Ü.; Gräslund, A. Differential membrane perturbation caused by the cell penetrating peptide Tp10 depending on attached cargo. FEBS Lett. 2007, 581, 2389-2393. [CrossRef]

22. Izabela, R.; Jarosław, R.; Magdalena, A.; Piotr, R.; Ivan, K. Transportan 10 improves the anticancer activity of cisplatin. Naunyn-Schmiedeberg's. Arch. Pharmacol. 2016, 389, 485-497. [CrossRef] [PubMed]

23. Xie, J.; Gou, Y.; Zhao, Q.; Li, S.; Zhang, W.; Song, J.; Mou, L.; Li, J.; Wang, K.; Zhang, B.; et al. Antimicrobial activities and action mechanism studies of transportan 10 and its analogues against multidrug-resistant bacteria. J. Pept. Sci. 2015, 21, 599-607. [CrossRef] [PubMed]

24. Turner, J.; Cho, Y.; Dinh, N.N.; Waring, A.J.; Lehrer, R.I. Activities of LL-37, a cathelin-associated antimicrobial peptide of human neutrophils. Antimicrob. Agents Chemother. 1998, 42, 2206-2214. [CrossRef] [PubMed]

25. Mohamed, M.F.; Abdelkhalek, A.; Seleem, M.N. Evaluation of short synthetic antimicrobial peptides for treatment of drug-resistant and intracellular Staphylococcus aureus. Sci. Rep. 2016, 6, 29707. [CrossRef] [PubMed]

26. Franz, R.; Kelly, S.L.; Lamb, D.C.; Kelly, D.E.; Ruhnke, M.; Morschhäuser, J. Multiple molecular mechanisms contribute to a stepwise development of fluconazole resistance in clinical Candida albicans strains. Antimicrob. Agents Chemother. 1998, 42, 3065-3072. [CrossRef]

27. Shen, L.L.; Pernet, A.G. Mechanism of inhibition of DNA gyrase by analogues of nalidixic acid: The target of the drugs is DNA. Proc. Natl. Acad. Sci. USA 1985, 82, 307-311. [CrossRef]

28. Tunitskaya, V.L.; Khomutov, A.R.; Kochetkov, S.N.; Kotovskaya, S.K.; Charushin, V.N. Inhibition of DNA Gyrase by Levofloxacin and Related Fluorine-Containing Heterocyclic Compounds. Acta Naturae 2011, 3, 94-99. [CrossRef]

29. Moreau, N.J.; Robaux, H.; Baron, L.; Tabary, X. Inhibitory effects of quinolones on pro- and eucaryotic DNA topoisomerases I and II. Antimicrob. Agents Chemother. 1990, 34, 1955-1960. [CrossRef]

30. Chen, Y.; Guarnieri, M.T.; Vasil, A.I.; Vasil, M.L.; Mant, C.T.; Hodges, R.S. Role of peptide hydrophobicity in the mechanism of action of $\alpha$-helical antimicrobial peptides. Antimicrob. Agents Chemother. 2007, 51, 1398-1406. [CrossRef]

31. Song, J.; Kai, M.; Zhang, W.; Zhang, J.; Liu, L.; Zhang, B.; Liu, X.; Wang, R. Cellular uptake of transportan 10 and its analogs in live cells: Selectivity and structure-activity relationship studies. Peptides 2011, 32, 1934-1941. [CrossRef]

32. Aguiar, L.; Biosca, A.; Lantero, E.; Gut, J.; Vale, N.; Rosenthal, P.J.; Nogueira, F.; Andreu, D.; Fernàndez-Busquets, X.; Gomes, P. Coupling the antimalarial cell penetrating peptide TP10 to classical antimalarial drugs primaquine and chloroquine produces strongly hemolytic conjugates. Molecules 2019, 24, 4559. [CrossRef] [PubMed]

33. Rubinstein, E.; Camm, J. Cardiotoxicity of fluoroquinolones. J. Antimicrob. Chemother. 2002, 49, $593-596$. [CrossRef] [PubMed]

34. Adikwu, E.; Brambaifa, N. Ciprofloxacin Cardiotoxicity and Hepatotoxicity in Humans and Animals. Pharmacol. Pharm. 2012, 3, 207-213. [CrossRef]

35. Qutrio Baloch, Z.; Raza, M.A.; Abbas, S.A.; Bukhari, S. Ciprofloxacin-induced Hepatotoxicity in a Healthy Young Adult. Cureus 2017, 9. [CrossRef] [PubMed]

36. Łegowska, A.; Dębowski, D.; Łukajtis, R.; Wysocka, M.; Czaplewski, C.; Lesner, A.; Rolka, K. Implication of the disulfide bridge in trypsin inhibitor SFTI-1 in its interaction with serine proteinases. Bioorg. Med. Chem. 2010, 18, 8188-8193. [CrossRef]

37. Lica, J.J.; Grabe, G.J.; Heldt, M.; Misiak, M.; Bloch, P.; Serocki, M.; Switalska, M.; Wietrzyk, J.; Baginski, M.; Hellmann, A.; et al. Cell Density-Dependent Cytological Stage Profile and Its Application for a Screen of Cytostatic Agents Active Toward Leukemic Stem Cells. Stem Cells Dev. 2018, 27, 488-513. [CrossRef] [PubMed] 
38. Evans, B.C.; Nelson, C.E.; Yu, S.S.; Beavers, K.R.; Kim, A.J.; Li, H.; Nelson, H.M.; Giorgio, T.D.; Duvall, C.L. Ex Vivo Red Blood Cell Hemolysis Assay for the Evaluation of $\mathrm{pH}$-responsive Endosomolytic Agents for Cytosolic Delivery of Biomacromolecular Drugs. J. Vis. Exp. 2013, 73, e50166. [CrossRef]

39. Saar, K.; Lindgren, M.; Hansen, M.; Eiríksdóttir, E.; Jiang, Y.; Rosenthal-Aizman, K.; Sassian, M.; Langel, Ü. Cell-penetrating peptides: A comparative membrane toxicity study. Anal. Biochem. 2005, 345, 55-65. [CrossRef]

40. Yandek, L.E.; Pokorny, A.; Florén, A.; Knoelke, K.; Langel, Ü.; Almeida, P.F.F. Mechanism of the cell-penetrating peptide transportan 10 permeation of lipid bilayers. Biophys. J. 2007, 92, 2434-2444. [CrossRef]

41. Ye, S.P.; Hsueh, E.J.; Yu, M.S.; Wu, H.; Wang, Y.C. Oral ciprofloxacin as antibacterial prophylaxis after allogeneic bone marrow transplantation: A reappraisal. Bone Marrow Transplant. 1999, 24, 1207-1211.

42. Wang, C.H.; Chang, F.Y.; Chao, T.Y.; Kao, W.Y.; Ho, C.L.; Chen, Y.C.; Dai, M.S.; Chang, P.Y.; Wu, Y.Y.; Lin, J.C. Characteristics comparisons of bacteremia in allogeneic and autologous hematopoietic stem cell-transplant recipients with levofloxacin prophylaxis and influence on resistant bacteria emergence. J. Microbiol. Immunol. Infect. 2018, 51, 123-131. [CrossRef] [PubMed]

43. Doan, V.P.; Yeh, J.C.; Gulbis, A.M.; Aitken, S.L.; Ariza-Heredia, E.; Ahmed, S. Levofloxacin versus Cefpodoxime for Antibacterial Prophylaxis in Allogeneic Stem Cell Transplantation. Biol. Blood Marrow Transplant. 2019, 25, 1637-1641. [CrossRef] [PubMed]

44. De Pauw, B.E.; Donnelly, J.P.; De Witte, T.; Novakova, I.R.; Schattenberg, A. Options and limitations of long-term oral ciprofloxacin as antibacterial prophylaxis in allogeneic bone marrow transplant recipients. Bone Marrow Transplant. 1990, 5, 179-182.

45. Trenschel, R.; Peceny, R.; Runde, V.; Elmaagacli, A.; Dermoumi, H.; Von Heinegg, E.H.; Müller, K.D.; Schaefer, U.W.; Beelen, D.W. Fungal colonization and invasive fungal infections following allogeneic BMT using metronidazole, ciprofloxacin and fluconazole or ciprofloxacin and fluconzole as intestinal decontamination. Bone Marrow Transplant. 2000, 26, 993-997. [CrossRef]

(C) 2020 by the authors. Licensee MDPI, Basel, Switzerland. This article is an open access article distributed under the terms and conditions of the Creative Commons Attribution (CC BY) license (http://creativecommons.org/licenses/by/4.0/). 